\title{
A HISTOLOGICAL STUDY OF THE MUCOUS MEMBRANE IN CHRONIC SINUSITIS,
}

$\mathrm{By}$

\section{T. KOBAYASHI}

From the Department of Otorhinolaryngology, Nagasaki Universitr School of Medicine. (Director: Prof. T. Goto)

The behavior of the mucous membrane of the turbinal in chronic sinusitis is not well known. I have planned to investigate the relationship between the histological ehanges of the turbinal and that of the sinus mucosa as a part of the pneumatizalion study in our institut.

I have observed histologically the mucous membrane of the maxillary sinus and the ipsilateral inferior turbinal in 100 cases and that of the ethmoidal sinus and the turbinal in 43 cases.

The results are as follows:

1) The histological changes of the turbinal were classified into three main types, namely edematous, infiltrative and fibrous types, after the classification of the mucosa in clronic sinusitis.

2) The mucous membrane of the inferior turbinal revealed mostly a edematouscehanges in chronic sinusitis of the edematous type and a fibrous changes in that of the fibrous type.

3) The changes of the middle turbinal was similar to that of the inferior turbinal, but the edematous type has higher incidence in the middle turbinal than in the inferior turbinal.

4) The edematous changes of the mucous membrane was seen more frequently in the sinus membrana then in the turbinal membrane.

5) From the forgoing results the author assumes that the change of the mucous membrane of the turbinal would be influenced by the local constitution such as the sinus membrane, thus having some relation to pneumatization of the sinus.

6) The author had studied the microscopical findings of the turbinal membrane, with particular attention to the cavernous, bodies whose magnified models were reconstructed after numerous microscopical photographs. It is believed that the muscular procces in the cavernous body is not a inflammatory product, but a physiological unit contributing to the contraction of the cavernous body. 


\title{
慢性副鼻腔炎における鼻甲介粘膜の病理組織学的研究
}

\author{
長崎大学医学部耳鼻咽咬科学教宣（主任：後藤敏期教授）
}

小梦藤琞

目次

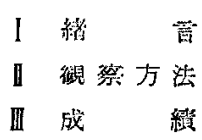

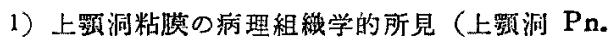
々粘膜病型の分類)

2) 下甲介粘膜の病理組秘学的所見並びに゙上颚润粘 怔所見との相互関係

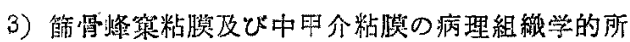

見之网者の相互関係

4) 下甲介粘膜所見と中甲介粘膜所見との相互関係

IV 考技

$\mathrm{V}$ 結 解

I. 緒

\section{言}

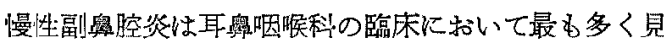

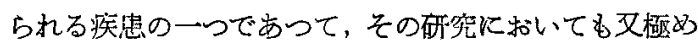
て多く且つ多様である。

本疾患の組織学的研究は Zuckerkandl 以来, 多数の 研究者が艺机ぞれの立場から幾多の業縝を䂝してきてい るが，近年に拈いてもなお相次いで新しい哬密が発表せ られており，とくに最近では，奥副奥腔の上皮，浸溜細

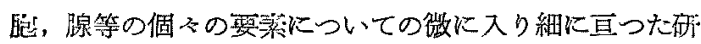
究が多く見られる上らになつている、㕛アレルギーの杜 場からの研管や，組織化学的研究も日を追つて発展し つ〉ある状洗である。しかしながら副舅腔炎に関して は，いぜん残された開题も多い。

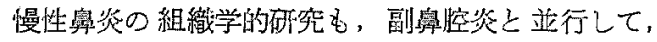
Zuckerkandl, Citelli, Seiffert Runge, 久体，芦原，

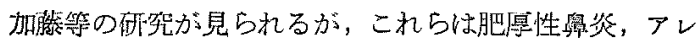

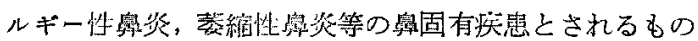

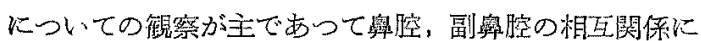
ふ扎ているものはすくない 加藤は肥學性鼻炎について

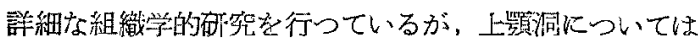
臨床所見について一部にふれているのみでその組舶所見 の梌訓は行つていない，近年になつて，望月が妁小照

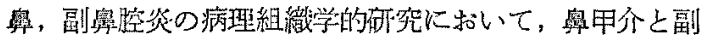

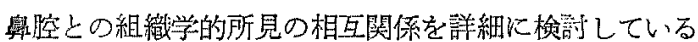

が，成人についてのこの源の研究はまだ見当らない，後 蕂教室に特いては先に中耳蜂窠の含気腔学的研究につい で，副尊腔の含気腔学的な立易からの研究を行い，既に 阿部，柴田，华田等の研究が発表されてきたが，私性副 鼻腔炎の体質的関保を再検討する意味において，副鼻腔

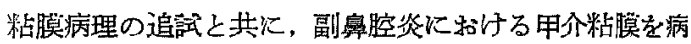
理組織学的に観察して, 副悬腔所見との相互関係につい て矿究し新しい知見を得たので報告する。

\section{II. 観察方法}

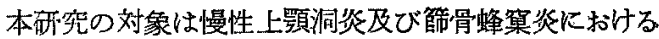
洞粘膜と，それに属する甲介粘膜であつて中でも上䫇洞 と下蚧の 組織所見の 対比観察に重点をおいて 検討し 广.

観察材料は長崎大学及び田川市立病院耳鼻科において 根治手術を受けた㭧者であつて，10才より55才に亘る 110 側，即ら下申介及び上顎洞 100 例，中甲介及び節骨 蜂窂 43 例で同一側より下甲介と中甲介を得た 33 例が含 まれている.これらの患者は年令的には10才1各，56才 1 名, 46才1䓃の他は，13〜19才 34名，20〜39才13

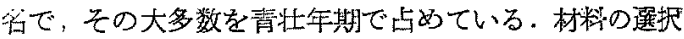
については，急性症状を呈しない，安定した慢性副鼻膑

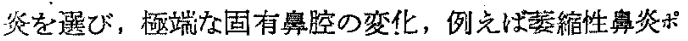

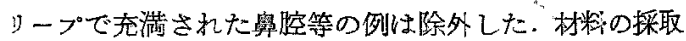

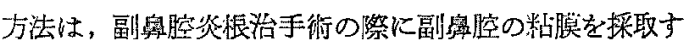
万と同時に同側の上镇洞に対しては下甲介，篩骨蜂柋に 対しては中甲介を取り，それぞれの甲介と副舆腔を1対 としては例とした．甲界粘臊の採取に当つてはでさるた けその一定部位（前・内・下蚫を中心とする）を選び， Хでさるた゚けキシロカイ表面麻酔のみで採取するように

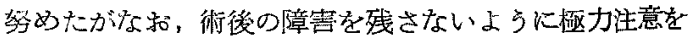
払つて採取した，又衎前に甲介糊莫の肉腿所見並びにニ

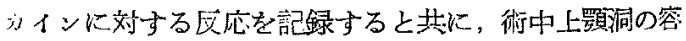

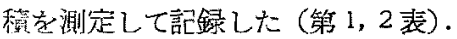

手術の祭摘出した洞粘膜及び切除された甲介粘膜は共 に10\%沓ルーリン国定とし，バフィン包埋にして染 色，穓祭に供したが，一部の列については連続切片を作 つて観察した。染色法は Haematoxylin-Eosin 及び 
第 1 表上颉洞・下丑介例

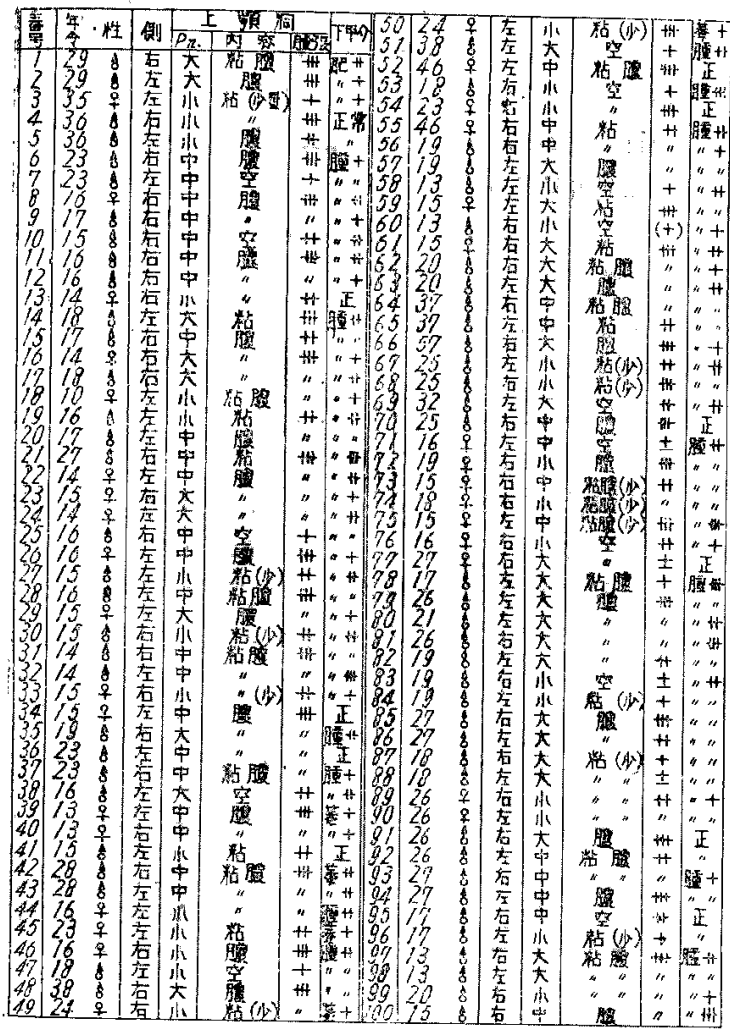

Masson を主とし、な掠Van-Gieson, Weigert 氏法 を併せ行い, Mucicarmin 染色, Unna-Pappenheim のPlasma 細胞染色飞時に併朋した。

\section{III. 成 綘}

1) 上颚洞粘膜の)病理組緎学的所見（上彯洞

Pn. 之粘膜病型の分類)

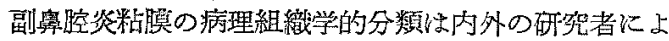
り種タなされてきたが，实際には同一粘膜内に和いても その部位により，各種の組織学的所見を呈しており，

Oppikofer 毛云つているょうに，一二の洞粘膜を一つ の組織型にして分類することには無理が伴うことは当然 であると考えられるが，しかし又一面，聠的な状態にあ

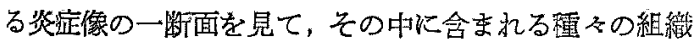
像をすべて表現しょうとする複雑な分類法は，組織像を

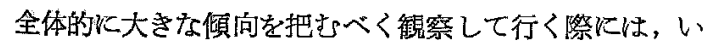
たずらに混乱をまねくのみであつて，この場合，各洞粘 膜の主徽たるべき組織像を知るようにつとめて、これた よってできるだけ単純に分類することが適当であり又，
第 2 表 簿骨䗋勧・中甲介例

\begin{tabular}{|c|c|c|c|c|c|c|c|c|c|c|c|}
\hline 番 & 年。 & fall & 暲骨 & 䗋赛 & 由田 & 23 & & t t & t女 & + & + \\
\hline 号 & 今 & 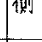 & 内容 & 腆熋 & & 24 & 169 & t & " & , & $\stackrel{(-)}{ }$ \\
\hline 1 & 198 & 右 & 炶 滕 & HtH & 堙 + & 25 & 198 & 右 & 粘 & H & $\leftrightarrow$ \\
\hline 2 & 196 & 左 & " & " & $"+$ & 26 & $46+$ & 右 & " & $"$ & $H$ \\
\hline 3 & 198 & t & 空 & 正 & $" \pm$ & 27 & $46+$ & 左 & 空 & + & + \\
\hline 4 & 198 & t. & " & $"$ & "H & 28 & 298 & $t_{x}$ & 炶腿 & $H$ & \# \\
\hline 5 & $27 \AA$ & t & " & + & " " & 29 & 238 & tr & $"$ & t\$ & $H$ \\
\hline 6 & 278 & 左 & " & 正 & $\leftrightarrow$ & 30 & $16+$ & $\overline{t_{1}}$ & 粘 & " & + \\
\hline 7 & 180 & 右 & 炶搭 & H & $4+$ & 31 & 198 & 右 & 䭪 & , & + \\
\hline 8 & 188 & 左 & 空 & 正 & $"+$ & 32 & $15+$ & 右 & 活 & $H$ & + \\
\hline 9 & 267 & 方 & " & & $"+$ & 33 & 189 & 㕕 & , & $t$ & + \\
\hline $\mathrm{IJ}$ & 264 & t王 & " & , & $\leftrightarrow$ & 34 & 158 & 7 左 & 呫亚 & $H$ & $H$ \\
\hline 11 & $20 \mathrm{~s}$ & 右 & 数蝇 & it & $1 "+$ & 35 & $16 ?$ & q 右 & : & * & + \\
\hline 12 & 201 & 左 & 滕 & $"$ & $H$ & 36 & 278 & 每 & 空 & + & $\leftrightarrow$ \\
\hline 13 & 178 & 右 & 空 & + & $\leftrightarrow$ & 37 & $25 \%$ & 右 & 䅦墙 & $H$ & \\
\hline 14 & 178 & t在 & A & 3 & $(-)$ & 38 & $16 \%$ & $\frac{1}{2}$ & 笣 & " & \\
\hline 15 & 278 & 右 & 粘 & H & + & 39 & 218 & $t_{x}$ & 新张 & H & \pm \\
\hline 16 & $27 \mathrm{~s}$ & 左 & 空 & H & 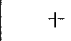 & 40 & 219 & 吕 & 空 & 王 & \\
\hline 17 & 174 & 右 & . & + & $(-)$ & 41 & 228 & 右 & 始脸 & ++ & \\
\hline 18 & 17 & 左 & $"$ & it & $(-)$ & 12 & 198 & 菏 & 暖 & 䋆 & \\
\hline 19 & 131 & 右 & 炶膗 & H & + & 43 & $19 \div$ & $t$ & I & 正 & \\
\hline 20 & 138 & $t_{I}$ & " & + & + & & & & & & \\
\hline 27 & $20 \%$ & 右 & 空 & + & $(-)$ & & & & & & \\
\hline & $15:$ & 右 & 暗 & " & tr & & & & & & \\
\hline
\end{tabular}

こうした分類が実際には行れれてきている．即ち Mannasse の分類に上る浮嘎型，浸潤型，線䊒型がこの上5 な考光方に迴切でありて，年田，加霜等多数の研究者が この考克方に従っている、私は牟田の方法に従つて観察 カることにした。

上頸洞の检索例は 100 例であるが，去の発省度の判定 括法の基準については，阿部，车田の研究があつて，研

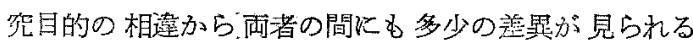
が，私は本田の方法をとることにした。即ち手術に際し

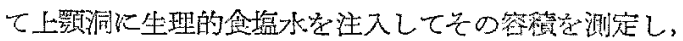

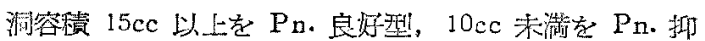
制型とし，その中間の值のものをPn. 扗等閉型とした。 この結果は第 3 表の成續が得られた。

即万 Pn. 良好型は総数 32 例 $(32 \%)$ で，そ心粘䐺病

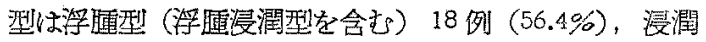
型 8 例 $(25.0 \%)$ ，線維型 5 例 (15.6\%)で苭つた. Pn. 抑制型では総数 31 例 $(31 \%)$ 05ち浮䐦型 8 例 $(25.8$ $\%)$, 浸潤型 4 例 $(13.0 \%)$ 及び線維型19 例 $(61.5 \%)$ で 离り，Pn. 中等度型 37 例て恃，浮連型 12 例 (32.5\%)， 浸潤型 15 例 $(40.5 \%)$ ，䠌維型 9 例 (24.3\%) であつた。

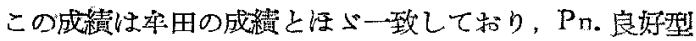


ではとの粘脱は浮腫性变化を主改とする傾向が强く、 Pn。和制型ではその粘膜以線䊒型がはるかに高率に現れ ていることを示している。

第 3 表 上顡润 $\mathrm{Pn}$. と粘膜病型

\begin{tabular}{|c|c|c|c|c|c|}
\hline & $\begin{array}{l}\text { 絵数 } \\
\text { (側) }\end{array}$ & $\begin{array}{l}\text { 浮腫琹 } \\
\text { 浮腫浸灌) }\end{array}$ & 浸潤型 & $\begin{array}{c}\text { 線洴型 } \\
\text { (線維浸潤) }\end{array}$ & 混合型 \\
\hline 良好 & 32 & $\begin{array}{c}18 \\
(56.4 \%)\end{array}$ & $\begin{array}{c}8 \\
(25.0 \%)\end{array}$ & $\begin{array}{c}5 \\
(15.6 \%)\end{array}$ & $\begin{array}{c}1 \\
(3 \%)\end{array}$ \\
\hline $\begin{array}{c}\text { Pn. } \\
\text { 中等型 }\end{array}$ & 37 & $\begin{array}{c}12 \\
(32.5 \%)\end{array}$ & $\begin{array}{c}15 \\
(40.5 \%)\end{array}$ & $\begin{array}{c}9 \\
(24.3 \%)\end{array}$ & $(2.7 \%)$ \\
\hline $\begin{array}{l}\text { Pn. } \\
\text { 抑制开 }\end{array}$ & 31 & $\begin{array}{c}8 \\
(25.8 \%)\end{array}$ & $\begin{array}{c}4 \\
(13.0 \%)\end{array}$ & $\begin{array}{c}19 \\
(61.5 \%)\end{array}$ & $\begin{array}{c}0 \\
(0 \%)\end{array}$ \\
\hline
\end{tabular}

上皮の変化，基礎膜，腺及び血管の組綏所見及びPn. との関係についてはこっには記載を消略して，下甲介の 項に执いて必覆に応でて記載することつするが，能田の

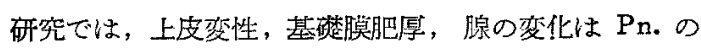
発育度によつて特別の差異を認め難く，浸潤細胞につい ては好酸球において浮埂型のものにや小高率に見られる とし，血管壁の変化炕括いては，Pn，中等型上り Pn. 抑制型と，粘俣の增殖性变化が高度となるに徒つて，管 壁は周囲組繶の圧迫による從属的变化と，血管自体の退 行変性を伴つた肥厚を示す多様の肥厚像が見られるが， これらの変化は各型粘脱を通じて血管壁肥厚像に特有の 差異は認め難いとしている.

2)下甲介粘䐉の病理組織学的所見並びに上顎洞 粘膜所見之の相互関係

鼻甲介粘脱の病理組織学的不究は内外共に古来数多く の研究が見られるが，とくに慢性肥厚性舅炎，アレルギ 一性离炎, 萎縮性鼻炎等のいわゆる固有鼻腔知患之され るものについての研究は枚挙にいとまない程である、中 でも Marx, Klesstaat, Citelli, Klans vogel, Runge, Zarnico, Zuckebkandl, 久保, 芦原, 茂川, 加藤等の すぐれた研究があり，近年では更に望月，岩茾等のより 陆細な研究子見られる.私は主として副鼻腔の観察に際 して用いたと同様な方法で，全体的な観察，即ち炎症反 応の中の大きな徽候についてその傾向の方向を求めそれ が上顎洞との関係に批いていかなる態度を示すかと云う 点の追求に主眼を㔚き，組織学的徵細構造の検討は他に ゆずることにした。たよ，腫脹体と云われるいすゆる海 綿体血管については，文献に余りその詳細な記載を見な いので，いさつか詳細に検䚯を行うことにした。

a) 浮腫, 結合織及び細胞浸潤

浮腫は全般的にみて上䫇洞粘膜に指ける上りも発生率 は低く，又個々の例に括いて子浮腫の程度は一般に軽度
であるが，数例において極めて高度の浮腫が認められた (これらの例は臨佅上肥厚性鼻炎之云いらる例が多く13 例中6例に見られた)。

浮腫の程度を高度 (全体的に著明に認める), 中等度 (広範囲に明らかに認めるが軽度のもの)，軽度（部分的 に軽度汇認める例方るいは全く認めないもの)の3段階 に分類してみると, 高度例 13 例, 中等度例 15 例, 軽症

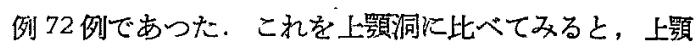
洞浮腫型 38 例 (これは殆んど全例が高度浮腫である)，

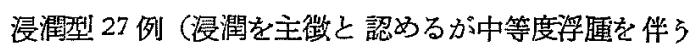
例が多い), 線維型（軽度の浮運を伴うるのが 可なり含 まれる）33例であつて，下甲介に秃、て浮埂発現率が はるが低率であつた. 又上頻洞浮腫と下甲实浮腫の相 互関保孫 4 表の如くで，上䫇洞浮重型38 例の下甲介 では浮腫高度 8 例, 中等度 6 例, 軽度 24 例, 又上㖽洞 漫溜型 27 例では下甲介の浮缠高度 3 例, 中等度 7 例, 軽度 17 例, 上額洞線䊒型33 例の下甲众に打いては, 下 甲介の浮通高度例 2 例, 中等度 2 例, 軽度 29 例であっ

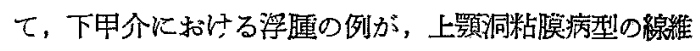
型に比して，浮尰型の場合約 4 倍の高率に出現してい る.

第4 表 上彯洞粘膜病型と下甲介琈腫

\begin{tabular}{|c|c|c|c|c|c|}
\hline $\begin{array}{l}\text { 上市了 } \\
\text { 上頟洞病型 }\end{array}$ & & 高 度 & 中等度 & 軽 度 & \\
\hline 浮 缰 & 型 & 8 & 6 & 24 & 38 \\
\hline 浸＼cjkstart閪 & 型 & 3 & 7 & 17 & 27 \\
\hline 線＼cjkstart維 & 型 & 2 & 2 & 29 & 33 \\
\hline & & 13 & 15 & 70 & \\
\hline
\end{tabular}

この浮腫は一般に粘脱固有層の 浅層部に著明であり て，深部には少く，とくにいわゆる海楾体血管層及び骨 膜層には稀であることは上頍洞粘脱におけるよりる一層 判然と認められる。しかして, 浮婳高度のものでは，結 合織線維の網状構造が認められるが，その網目の結合織 は上䫟洞粘膜に見られるすのよりは，一般に強靱な感し を受汁る例が多く認められた。加藤も慢性肥厚性鼻炎に

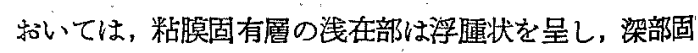
有層の結合織增生を示したものが多く，とくに慢性上䫑 洞蓄膿症を伴つた慢性肥厚性鼻炎に和ける下甲介粘朕は 粘膜固有層の全層に涉つて結合䋨の增生を示す例が多い と述べているが，肥厚性鼻炎に限らず，下甲介の慢性炎 症に和いては，一般に浮聥上りる結合織增生の方が僈位 に立つているように思われる。 
結合織の状態は又慢性奥副番腔焱の病理組織に执いて 重要な因子であるが，上顎洞に扣いてはPn. Jehemint のもの>粘䐺に線䊒型が高率に見られることは既に知ら れている通りである。．下众粘点においては，上顎洞絬

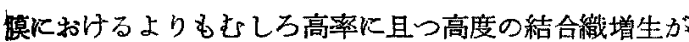
見られるが，上顎洞と下甲介の相互関倸を浮連之同様に 対比してみると第 5 表の通りである。

第 5 表 上㓋润粘膜病型と下甲介結合織

\begin{tabular}{|c|c|c|c|c|c|c|}
\hline 病型 & & 合維 & 高 & 中等 度 & 軽 & \\
\hline 浮 & 隀 & 型 & $\begin{array}{c}12 \\
(31.5 \%)\end{array}$ & $\begin{array}{c}10 \\
(26.3 \%)\end{array}$ & $\begin{array}{c}16 \\
(42.2 \%)\end{array}$ & 38 \\
\hline 浸 & 潤 & 型 & $\begin{array}{c}7 \\
(25.9 \%)\end{array}$ & $\begin{array}{c}3 \\
(11.3 \%)\end{array}$ & $(63.0 \%)$ & 27 \\
\hline \multirow[t]{2}{*}{ 袙 } & 䊒 & 型 & $\begin{array}{c}12 \\
(25.9 \%)\end{array}$ & $\begin{array}{c}13 \\
(11.1 \%)\end{array}$ & $\begin{array}{c}8 \\
(63.0 \%)\end{array}$ & 33 \\
\hline & & & 31 & 26 & 41 & \\
\hline
\end{tabular}

即ち全層に亘つて結合織の 增生著明のものを高度と し，結合織の堌生を㒛ぬないか部分的に軽度の增生が見 られるるのを軽度とし, その中間のものを中等度として 分類寸ると, 高度のもの 31 例, 中等度のもの 26 例, 軽 度のもの 41 例であつて，上颚洞粘膜病型別に見れば， 浮庫とは全く逆に，上顎洞線維型で下甲介の結合織は高 度に，上顎洞浮腫型では下甲介結合織は軽度に傾いてい ることが見られる。

叉いずれの例に招いても結合織の普生は一般に梁部固 有層に著明であることは前述の通りであるが，結合織增 生の著しい例に㧅いては，固有層浅層部に和いてる上皮 下に接する如く帯状に，細長㤠の核をもつて，あたかも 流九る如き観を呈しているものも数例認められた．

細胞浸潤は浮腫々同様に固有層浅層に最も著明であり 腺周围にも見られるが，梁部血管層にむで及ぶ例はごく 稀である. 漫潤の高度の例では淍胞状に密集する像が見 られることは上顎洞粘膜と同様であるが,このような高 度の浸潤例は比較的少数で一般に細胞浸潤は上䫇洞に拉 けるよりも軽度である，しかしながら100例の中で浸潤 の全く認められない例は1例も認められず，浸潤が起る

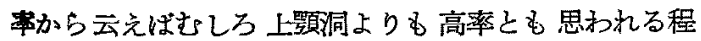
でむたか子下甲介における慢性炎所見の第一の徽候と さえ感ぜられた. 浅在固有層の全体酒る高度の漫潤を 認める例を高度浸潤とし，極く小数力所僅少の浸潤栄 を認めるか，広範囲ではあるが散在性汇浸潤を認めるも のを軽度としその中間のものを中等度として分類してみ
ると, 浸潤高度のるの 16 例, 中等度のもの 28 例, 軽度 のわの 56 例が数光られた，これを上顎洞粘償病型別に みると第6表の通りであつた。

第 6 表 上颚洞粘膜病型亡下甲介細胞浸淈

\begin{tabular}{|c|c|c|c|c|c|c|}
\hline 病型 & & & 䅅度 & 中等 度 & 高 & \\
\hline & 維 & 型 & $\begin{array}{c}13 \\
(29.7 \%)\end{array}$ & $\begin{array}{c}11 \\
(33.2 \%)\end{array}$ & $\begin{array}{c}9 \\
(28.1 \%)\end{array}$ & 33 \\
\hline 浮 & 㯾 & 型 & $\begin{array}{c}25 \\
(65.8 \%) \\
\end{array}$ & $\begin{array}{c}10 \\
(26.3 \%)\end{array}$ & $\begin{array}{c}3 \\
(7.9 \%) \\
\end{array}$ & 38 \\
\hline \multirow[t]{2}{*}{ 浸 } & 潤 & 型 & $\begin{array}{c}16 \\
(59.3 \%)\end{array}$ & $\begin{array}{c}7 \\
(25.9 \%) \\
\end{array}$ & $\begin{array}{c}4 \\
(14.8 \%)\end{array}$ & 27 \\
\hline & & & 56 & 28 & 16 & \\
\hline
\end{tabular}

即ち上㖽洞漫濯型に和いてその下甲介はむしろ 細胞 浸潤方低率に現れている，今之を角度を变えて上罰洞 $\mathrm{Pn}$. 分泌物及び下甲介の腫脹の程度によつて分類してみ ると第7表の如くである。

第7 表 上颚洞 $\mathrm{Pn}$. 分泌物，甲介尰脹と下甲介 細胞浸湘

\begin{tabular}{|c|c|c|c|c|c|}
\hline & & \multicolumn{4}{|c|}{ 下甲介細胞浸潤 } \\
\hline & & 軽 度 & 中 等 & 高 & 等 \\
\hline \multirow{3}{*}{ 上咢洞 Pn. } & 良 好 & 20 & 9 & & 3 \\
\hline & 中 等 & 23 & 9 & & 4 \\
\hline & 抑 踤 & 13 & 10 & & 9 \\
\hline \multirow{3}{*}{ 上频洞内容 } & \multirow{3}{*}{$\begin{array}{l}\text { 樶 } \\
\text { 粘 } \\
\text { 空 }\end{array}$} & 20 & 15 & & 3 \\
\hline & & $\{19$ & $\left\{\begin{array}{l}4 \\
0\end{array}\right.$ & & 13 \\
\hline & & 16 & 9 & & 10 \\
\hline \multirow{4}{*}{ 下朋介䚪脹 } & 高 度 & 32 & 16 & & 8 \\
\hline & 跬 度 & 16 & 7 & & 5 \\
\hline & \multirow{2}{*}{ 正 常 } & 8 & 5 & & 3 \\
\hline & & 56 & 28 & & 16 \\
\hline
\end{tabular}

即ち Pn. 良好型に比してPn 抑制型でとの下甲介の 細胞浸潤が高率に見られるが，内容別では，膿性，粘性 に比して，内容空のものに(これは一般に上罰洞炎の柽 症(例を示すが) むしろ下甲介の細胞浸㵎が高率に現れて 括り，又下甲介の臨床所見上董脹高度のもの上りも正常 (これは疅脹が認められないでもしろ軽度萎縮例も含む が）例に細胞浸潤が高率に現れている。この結果はある

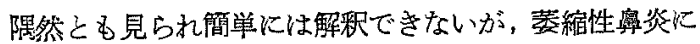
おいて一般とその上頍洞に Pn. 抑制型が多く認められ ていること〉思いあかせるとこれ等の関保にはなんらか 
の甞義がひそんでいるように思われる。

一方個大の浸㵎細胞苟の病理学的意義, 形態学的観察等: に関与研究は，河村，片岡，西端，北行，後藤，本间，

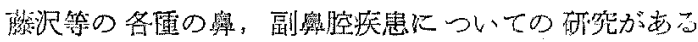

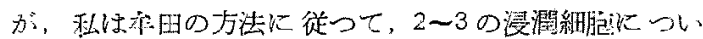

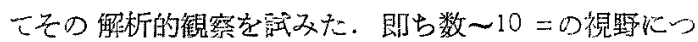
いて白血浗分類の要領でリンパ冰，形留細苞，诗酸冰，

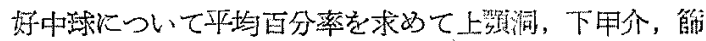
甪蜂巢及び中甲介について比較観察を行つた，その結果

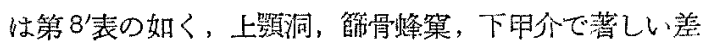

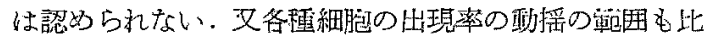

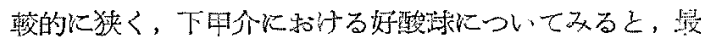

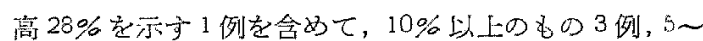
$9 \% の$ ○の2 例である. 今仮にこの28例を好酸球の间 度浸潤例之して下甲介の浮蕾との関保を見ると第 9 表の 如くで斿る。

第 $8^{\prime}$ 表 漫泪細胞の平均百分率 $(\%)$

\begin{tabular}{|c|c|c|c|c|}
\hline & リンパ & 形質細胞 & 好酸球 & 好中珠 \\
\hline 上疑 洞 & 63.0 & 29.7 & 3.1 & 5.2 \\
\hline 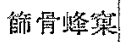 & 69.3 & 20.5 & 6.3 & 3.9 \\
\hline 下甲 众 & 69.4 & 23.4 & 3.7 & 3.5 \\
\hline 朋早介 & 71.2 & 21.0 & 5.2 & 2.6 \\
\hline
\end{tabular}

第 9 表 下甲介に和ける浮楩と好酸球

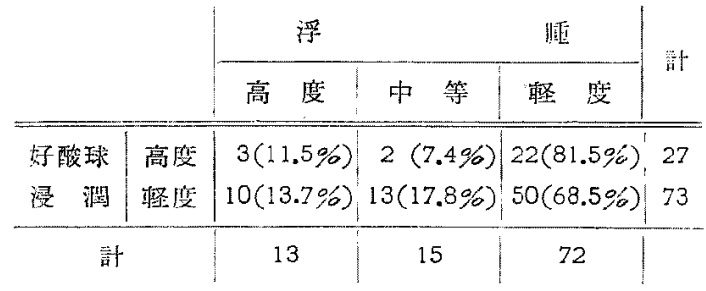

即ら下甲只の 好酸球浸潤高度例 27 例の上颚洞に括い ては类の好酸球の平均百分率は $3.7 \%$ に対して，下甲介 の好酸球浸洞軽度例 73 例の上敛洞では约酸球百分率は $2.9 \%$ を示し大差が認められない，下甲仝浮嗹との関俰 でも表偟示如く大きな差は見ら机ない，リンバ球，形 質細胞，好酸球，好中球共に上须洞粘膜病型別に見て著 しい差は認わられない" 即ら浸潤細胞については, 名 越，加藤，藤沢，白川，Hansel 等の云ら如きアレルギ 一性病変に見られるような特異の所見は認めることがで きなからた。これは，研究材料 (対象)の差によるもの か，観察の相違によるものか，一概には云えないが，恐
らく前者によるものであろう。しかし又河村，菓地，山

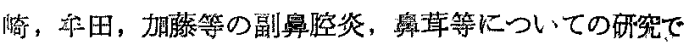

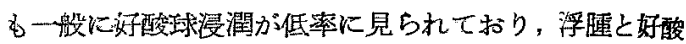
泳浸潤との関倸についてはまだまだ研究の余地が大い水 残されていると見ることができよう。

第 $8^{\prime}$ 表 上颚洞粘膜病型と下甲介浸墛細胞 平均百分率

\begin{tabular}{|c|c|c|c|c|c|}
\hline & & \multicolumn{4}{|c|}{ 下甲介浔潤細胞 $(\%)$} \\
\hline & & リンパ球| & 形質細胞 & 好酸球 & 好中球 \\
\hline \multirow{2}{*}{ 上彯洞 } & 線維型 & 71.2 & 19.8 & 4.7 & 3.6 \\
\hline & 浮涷型 & 66.0 & 26.3 & 3.1 & 3.7 \\
\hline 病型 & 浸澗型 & 67.3 & 24.8 & 3.4 & 3.5 \\
\hline 全 例 & 平 均 & 69.4 & 23.4 & 3.7 & 3.5 \\
\hline
\end{tabular}

形買練胞はリンハ球に次いで多く見られる細胞であつ てその出現率は表に見る勍く，各洞，各甲介間に著しい 差異が認められない，本細胞の発生については，リンパ 球説, 細網細胞説, 血管外㬴等の諸説があるが，この点 の検討は私の目的とするこころではない，崧柱として 粘脱病型と形質細腿の出現率との関俰について検討した のであるが，形質細胞についても好酸球と同じくあまり

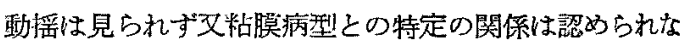
かつた。

以上下甲介の浮缰，結合織及び細胞浸潤について観察 してきたが，これをるとにして，上頸洞粘膜について行 つたと同樣に，線維型，浮腫型，浸潤型に分類して上筼 洞の分類と刘比してるると第9'表に見る如く，副鼻腔に 比して下甲介は線維型，浸潤型が高率であつて，一般に副

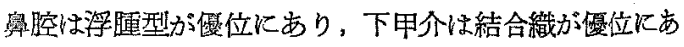
るよらに認められるが，上顎洞浮蕾型と下甲介浮随型， 上䫟洞線維型と下申介線維型との間飞は明らかな相関吕 認められる。

第 $\quad \mathbf{9}^{\prime}$ 表

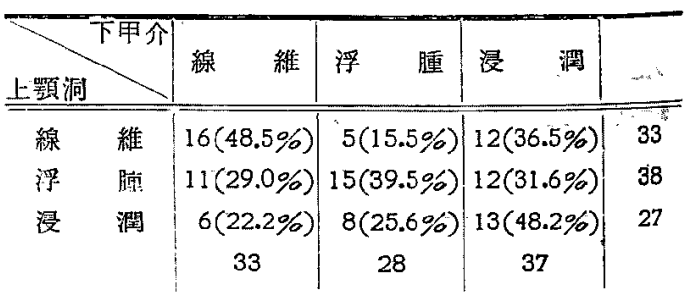

b）腺についての就究を文献でみると，その発生、形 
態に関するものでは Kalli us, Brunner, Valleri, 人 保等の報告が見られるが，最近岩壮は形態学的に詳細な

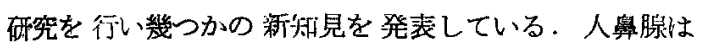
Stöbr, Schumacker, Heiss 等の研究以来一般には混 合腺説が認められているが, 又摮液腺, 粘液腺について

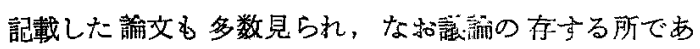
る。こ祅に対して岩井は，人奥腺はすべて混合単腺であ つて純獎夜腺，純絬液腺の存在を否定し，その発育につ いては10才ですでにほメ゙完全に発青し，充分に㙨能を 営むこ之を認めて，Valleri の20才完成説を否定して

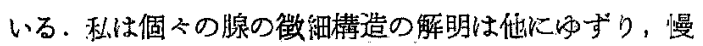
性副鼻䐩炎において腺がその全体的な分布之㙨能にどの ような態度を示すか，又鼻と副奥腔との間において腺の 示す態度に何等かの相関が見られるかどらがついて检 討した。

鼻腺の数については，下甲介では一平方 $\mathrm{cm}$ に約 150 万と記載している文献も見られるが，又強い個体差，部 位差があることは Oppikofer Bargmann, Bailey, Schieferdecker 等多くの斫究者が認めている，しかし て下甲介においては上頡洞に甜けるよりもはるかに豊富 に見られることは Krause, Luschka, Eggston and Wolff, Stöhr, Bargmann 等に限らず，多数の矿究者 が認めている通りであつて私の例化执、ても文同㥞であ つた。私の標本では甲介粘朕も副鼻腔粘朕もなるべく一 定部位を取つて検索につとめた。

全体的にみた場合下甲介が一般に腺に富むことは前述 の通りであるが，こつにも文可なり甚しい個体差が認め られた。 今切片全体に腺が広く見られる例を增加とし， 切片の1 数個処湶の小集団が認められるような例を 減少例として分類してみると, 增加例 27 例, 中等度例 38 例, 減少例 38 例が観察された。 上顎洞粘脱では腺を 殆んど見ない例から，可なり多数認める例をであるが， 下甲介之同様に分類してみると增加 16 例，中等 58 例， 減少 26 例であつた. 下甲介の腺の增減と上顎洞粘膜病 型との関係第 10 表に見られるが，上䌿洞線維型の下 甲介は腺增加例が多く見られ，上顎洞浮婳型の下甲介に は腺減少例が多く譛められた。 下甲介の粘膜病型別にみ てもほぶ同様の傾向が見られたが，上顎洞と下甲介が粘 膜病型に和いて相関を示す事実から当然の結梁とみられ ろ、加藤は小児副鼻腔炎飞未いて，腺の多宾と年令との 関係では特別の関係がないとし, 粘䐉病型では浮腫型よ りる線維型にや〉多く認めている。年田は副鼻腔 Pn. 琶式による腺組織の変化の程度を観察して, 腺の発達状
第 10 表 腺（下甲介）增減と上嫩润粘脱病型

\begin{tabular}{|c|c|c|c|c|c|}
\hline 病 & & 減 & 增 & 中 & 減 \\
\hline 楾 & 稚 & 型 & $13(39.4 \%)$ & $8(24.2 \%)$ & $12(36.4 \%)$ \\
\hline 浮 & 䨄 & 型 & $3(7.9 \%)$ & $19(50.1 \%)$ & $16(42.1 \%)$ \\
\hline 漫 & 澗 & 䍿 & $10(37.0 \%)$ & $7(26.0 \%)$ & $10(37.0 \%)$ \\
\hline
\end{tabular}

態はPn. 羿式之特別の関係はなく，むしろ浸潣の盛ん なるのに腺增殖がや入著明であるとしているが，下甲介 についてみてもその上顎洞 Pn. 型式との関保倸異性 は認められなかった，腺の肥大之萎縮については，立 田は副自腔粘腺の 腺について, 腺組織の 諸変化中最\& Pn.による著明な差異の諝められる点としてあげている が，下甲介についてみると，第11表の如く，腺の肥大

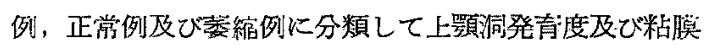
病型放倠察してみても，何等一定の相関々係を認める ことができなからた.

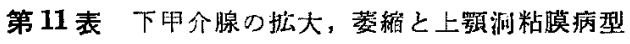

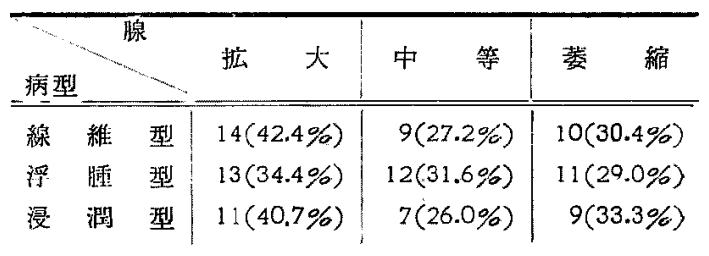

c) 血 " 管

先ず蕾脹体と呼ばれる梁部血管層はいわゆる海綿体血 管の集合であって，鼻介粘膜の組䋨構造の中で副學腔の それと最す異なる部分であり，質的にはむしろ唯一の相 異点之云うことができる。蕾脹体についての研究は灭 Zuckerkandl 飞よつて始めて䒺統的に研究され， Zarniko, Cittelli, Kopetzky, Schieferdecker, Klausvogel, Mink, 久保, 芦原, 加藤, 望月等の研究が相 次いで発表され相䋠つて次第にその組織学的知見を加光 てきたが，上皮，腺，浸潤細胞等の研究に比して，睡掁 体に関しては比較的研究も少なく，新しい知見に乏しい 感じをま妨が机ない，即ち我が国での慢性鼻炎の組織学 的嗰究の中で最も詳細なるのとみられている加藤の論文 に和いても，海綿体血管については数行記載されている が他の部分に比して簡単であり知見に乏しいように思わ れる，むしろ芦原，望月のるのに尰張体についての詳縕 な観察が見られるのであるが，私も海綿体血管について は特にや小詳細な観察を試みた。即ち比較的大きい切片 
第 1 目 血管海紸体連統切片

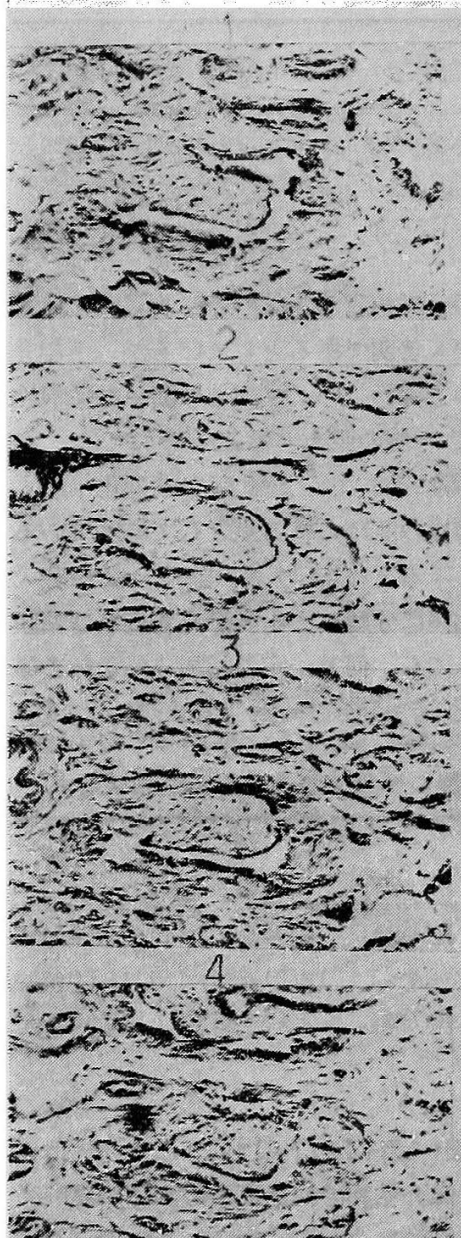

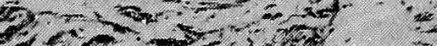

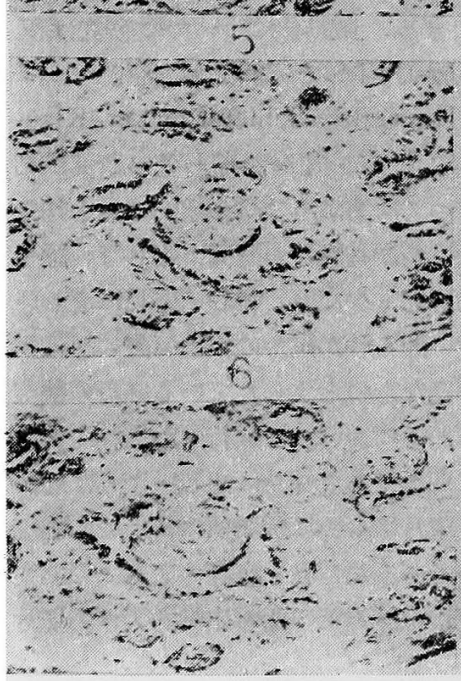

第 2 図 血管海綿体筋隆起連続切片
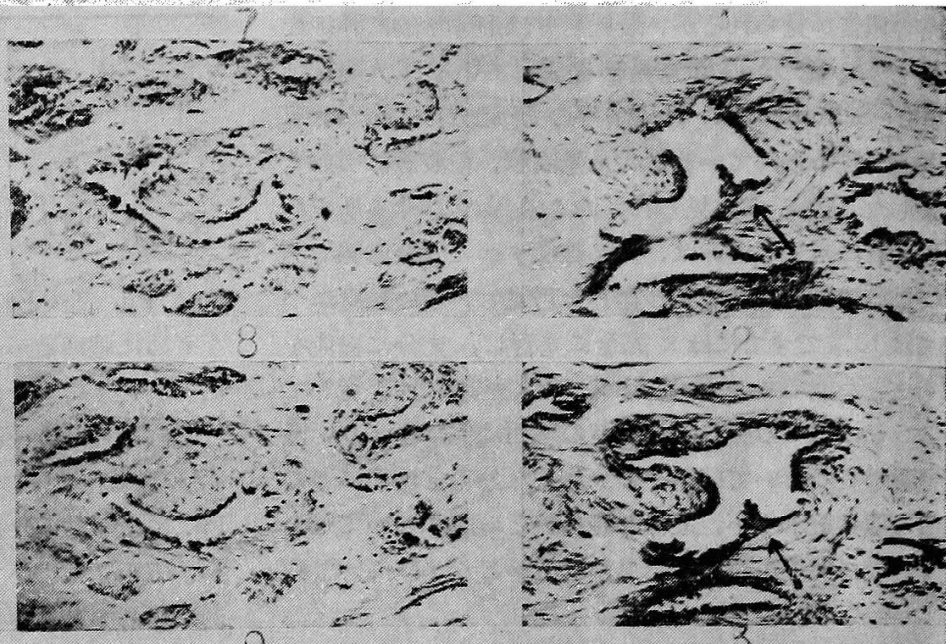

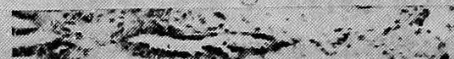

2.

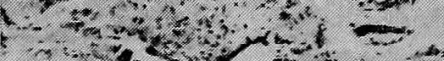

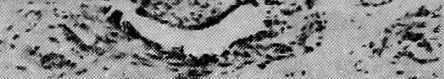

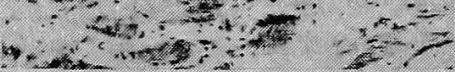

-

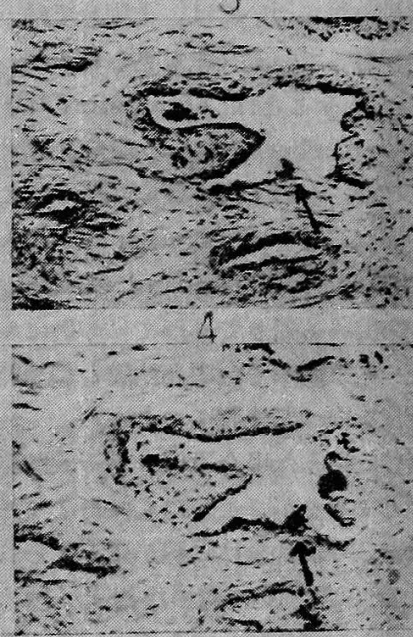

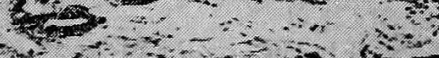

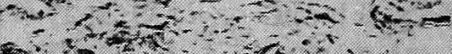

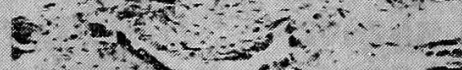

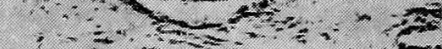

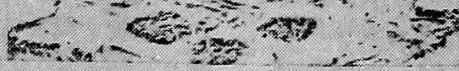

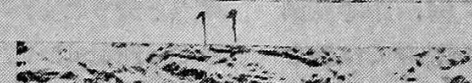

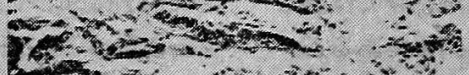

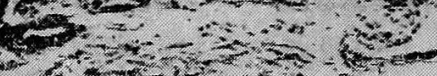

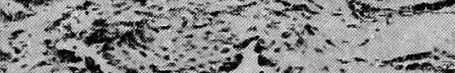

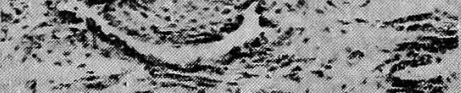
2. -

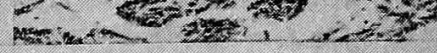

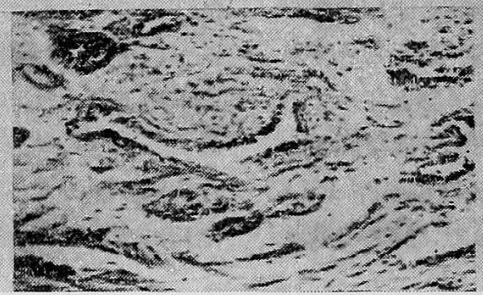

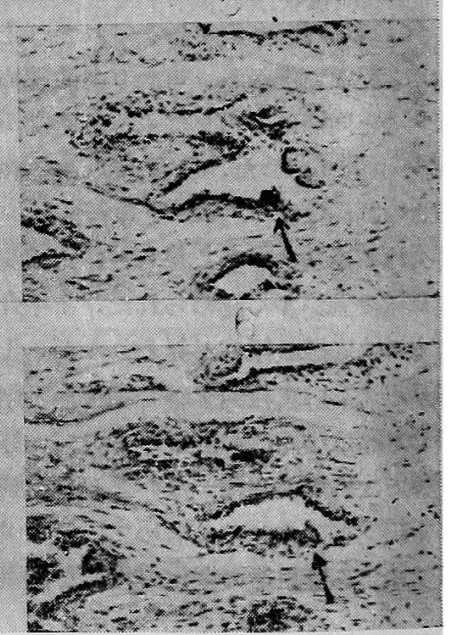


を得られた例及び剧に死体より得た肉眼所見で正常と認 められた数例について連続切片を作り，これを同倍率の 拡大写真に取つて腫脹体全体としての構造並びに血管壁 の立体的観察を行つた、この際写真の一部については血 管の内腔を実体とする複構模型を作成して観察の便に供 した（第 1，2，3図）．染色はマッッンを主とし，ワン・ ギーッン、ワイゲルト及びへマトキシリン・エオジン染 色を併せ観察を行つた。

第 3 図血管海線体復椾裺型
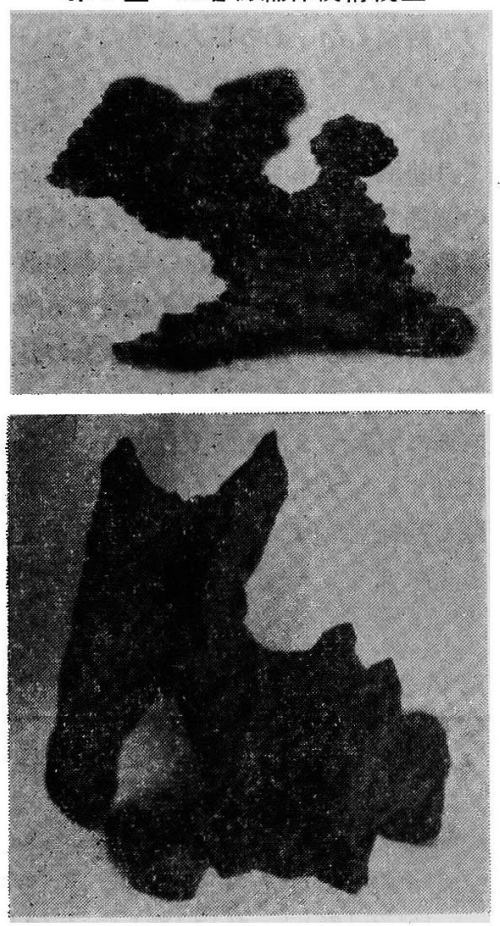

管壁の肥厚は薄いものと極めて厚いものととの差が著 しく(この際肥厚と云う言葉は不適当と考えるが), い ずれが病的かも問題であるが一応壁の厚さによつて 3 段 階に 分類してみると薄い例（一）64\%，中等度のもの (十) 15 例, 厚いもの (H) 21 例が钼察された. これを 上顋洞粘朕病型，下甲介の粘朕病型及び下甲介の腫脹の 程度によつて分類した結果は第 12 表の如くであつた。

即ち管壁肥厚高度のものについてみても，上顎洞粘膜 病型別では浸潤型に最高率である。これを下甲介の粘膜 病型別に見ると湶稚型に最高率であり，更に下甲介の臨 㾁所見河では柽症例, 即ら孟登退, 発の最も軽度な群に 管壁の肥厚が最高率に現れている．上頴洞粘膜と下甲介 粘膜との病型でいある程度の相関が認められたにも拘ら
第 12 表、下甲介海線体血管壁肥厚之上顎洞・ 下甲介病型及び下甲介腫脹

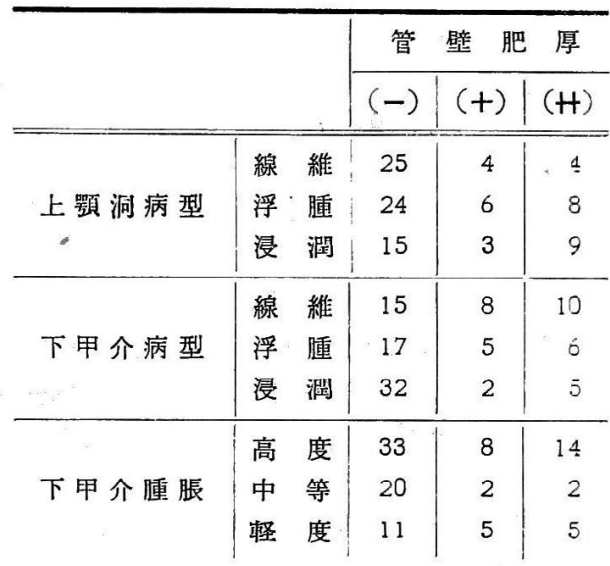

ず，管壁の肥厚が 両者の間で 相反する傾向を示してお り, 従つて管壁肥厚と粘膜病型との関係では関連性が認 め難いことになるしかしながら又，各例を詳細に観察 する時は, 浮腫, 結合織增生, 細腿浸潤あるいは上皮の 変性等の炎症所見と, 管壁の肥厚との間にも特別の関俰 が見られず炎症所見の軽幑な例にも碾く管壁の高度肥厚 が見られることは，下甲介所見において軽症例に最も多 く管壁肥厚の高度例が見られる点からもらかがえるので あつて，この間の説明に颃いては管壁肥厚は局所体質に よると考えさるを得ず, 局所炎症の防禦にもなん等かの 関係があるように思われる・いわゆる筋隆起については 芦原，加藤，望月等の観察が見られるのであるが，その 記載を見ると, 加藤は, 腫脹体組織子又管壁の肥厚を示 乙特に内膜及び中䐉に沶いて著明に認められ，これ等の 中には管腔の肥厚增殖強度にして管腔内に筋隆起として 突出せるを認めたものありとし，声原は，血管壁の一部 管内に增殖突入せる部分において云々とのべ, 望月は, 幼小児粘膜に関して，3〜4才の年令では中等度の病変 ある者では内膜は肥厚し不鮮明となり, 比較的容易に内 腔が突出し蔴くポルステル状の所見を呈すると記載して いるのであるが，これは恐らく，海綿体血管壁の内腔へ の突出部分について述べているものと考光られるのであ つて, 若しも管壁が肥厚增殖した結果かつる変化の生し たものであつて, 病変の強いことを示するのであるとの 見解であるとするならば，当を失した観察であると思わ れる．私は連続切片によつて海綿体構造の観察を行い， 復構模型を参考にして検討した. 又管壁の肥厚の状態と 周囲の結合織増殖の状態について, Masson, Van.Gie- 
son, Weigert の各染色標本を 対照しつ〉観察を 詪み

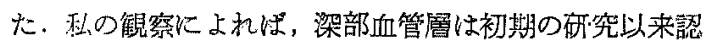
めらてている如く，いわゆる海綿体構造をなす血管群で あって大小の血管腔が連絡して網状に連らなっている。 しかしこの網目はそ水忹ど多いものではなく，相当部分 はむしら樹枝状を呈していると判断される. 即ち比較的 大きな内腔を持つものは主枝であつて，その近くに散在

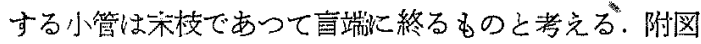
にも見られる如々，その盲端部分に打ける切片の像は， あたかも小血管が結合織の増殖あるいは筋層の变性によ り消失しつ〉あるかの如く見られるが，これを連続切片

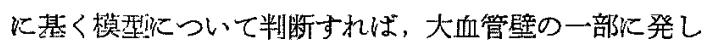

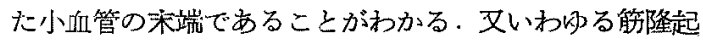
はその大部分のものが海線体の各管腔を連絡する部分即 ら各血管腔間の隔壁するいはヒダとでも云うべき部分の 1断面像であつて，酉接には管壁の肥厚，增殖とは無関 倸である。たが形の上では管壁の肥厚によつて笑出像 が，厚く円味を带びてくるかけであるが，それと共伣管 壁の形即ち凹凸の多等あるい、愔脹の度合等によつてそ の断面像は複雑に变化する。芦原はこの筋隆起の著明な 部分儿は屡な弾力線嶕が集合している例が多いとのべて いるが，私の観察です同様であって，それらの例は血管 壁周囲の結合織の增殖著明な例であって，隆起部分飞特 いても，内脱及び中脱はその他の部分之著しい差異は認 められない，文蟣細な弾力線䊒の集合は短隆起の型を呈

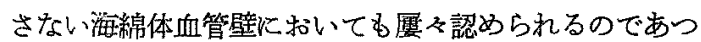
て，しかもその集合部分はおつむ双血管壁の横の断面上 相刘する2ヶ処にあうて，若しこの血管が収縮を示せば 前記 2 カ処の部分が内腔に向って笑出してくるるのと予 想される. 即ちこの部分が，それが収縮しているといな いとに拘らず，绦接する海綿体腔への連絡部分の中心に 相当するものと考学られる．この部分は模型的に考える ならば，模型の宿凹部分あるいはくびれの部分に相当す るもので，模型が膨脤してくるとこのくびれ部分は型の 上で性の部分との判別が困難となるが，実際には，一 般にこのくびれ部分飞細い弾力線維の集合像が見られる 例が多く，従つて弾力線維像炕よつて，収縮した場合内 腔に向つて突出してくる（模型においてはくびれとな る）部分を知る事ができるのである，又笳隆起が腫脹体 の㙨能にどの上うに影響しているか，觔隆起々機能との 関係を知る 目的で下甲介の 臨床所見と笳隆起との 関係 (第 13 表) 及びニカイン・アドレナリン反応との関倸に ついても检䚯を試みたのであつたが一定の結果を得るこ
とができず，今後なお検討を要する問題と考えられる。

第 13 表 下甲介肥大之海線体筷隆起

\begin{tabular}{|c|c|c|c|}
\hline 隆 & - & + & $H$ \\
\hline$H$ & $25(45.4 \%)$ & $18(32.8 \%)$ & $12(21.8 \%)$ \\
\hline+ & $10(41.6 \%)$ & $9(37.5 \%)$ & $5(20.9 \%)$ \\
\hline- & $10(27.6 \%)$ & $4(19.1 \%)$ & $7(33.3 \%)$ \\
\hline
\end{tabular}

管腔の拡大については，これもとの程度によつて3 段階に分けて観察した. 即ち抝大著明のもの $($ H) 11 例, 中等度 (十)のもの.25 例，認められないもの(一) 64 例 が得られたが，これと粘䐉病型 (上顎洞，下甲介其见) との関係では特別の関係は見られなかつた，たが下甲介 の肥大との関係では肥大高度のるのに拡大著明例が高率 にみられ，望月が小児蕆甲介において，娄縮性所見が小 览に多いことはその婳脹体が収縮を左右する所の滑平能 の正規的な弾力作用と，血管壁の緊張状態の良好さに基 くもの解しているが，卡の上らな見方からすれば私の 成續も又同様に判断することができよう，即ら下岉介肥 大, 蕾脹は必ずしも浮腫，結合繶の增加のみでなく，海 綿体血管壁の持続的な機能消失に上る扰大が大いに関与 していると見てよく，一般考えられている通りであ る.

第 14 表 下申介肥大と海綿体血管搪脹

\begin{tabular}{c|c|c|c}
\hline 拡脹 & - & + & $H$ \\
\hline \hline 皅大 & - & H \\
\hline$H$ & $34(61.7 \%)$ & $13(23.7 \%)$ & $8(14.6 \%)$ \\
+ & $14(58.1 \%)$ & $8(33.3 \%)$ & $2(8.6 \%)$ \\
- & $16(76.1 \%)$ & $4(19.1 \%)$ & $1(4.8 \%)$
\end{tabular}

上䫑洞における血管の変化は, 細胞浸㵎の状態と相要 つて，粘阅の炎症型式の表現として主要な因子とされて いる. Hansel は慢性炎に打いては著明な数の增加が あり，壁の肥厚，線維化が見られるとしている．近来 Allergie 研觉の進歩伴つて, 血管の変化は一算重要 視されてきたが, Eggston and Wolff も㿻管の変化 は副鼻腔炎粘朕の主徽としてこれを重要視している．加

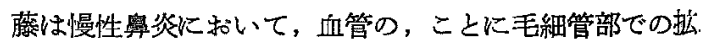
張性と血液充盈を認め血管壁は一般に肥厚性で結合織の 增殖が著明で，碃子様変性，萎縮所見を呈する例る認》 られるとしている。私もまた辺緑小血管の著明な拡張 例, 硝子様变性と思われる所見も認めたが，こ机等の変 
化は浸潤著明例にや〉多く認められるだけで，粘周病型 别にみてもその他の备所見との関保においても特別の頃 拘は認められなかつた。仁保，白堠の他管壁のフィ

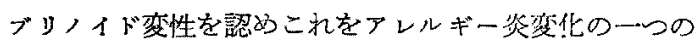

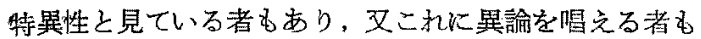

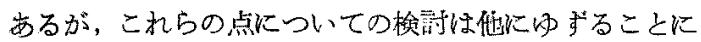
した。

上皮並に基礎脱については本邦では加滕，衣门等の詳

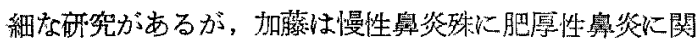
して，下甲介殆えどいす゚れの例です軽度乃至高度の」 皮細胞の增殖肥厚を認め，且つ上皮緗胞相互の結合性の 減弱によりその観粗橉上なるものが多いが，特に上㖽洞 蓄膿症を伴う例に著しいとしている。愁の例はす心゙て副 臿腔炎を対照にしたものであるが，上皮正䇰と見られる ものは1例もなく，又上皮細胞の增殖肥厚例よりも脱落 粗楉化を認める例が多く認るられた，上皮の変化を高度 H，中等度H，軽度＋に分頻してみる上，病变高度例 （脱落粗糖化䈐るしく，円柱上皮を認めない）35 例，中 等度 (ごく一部に円柱上皮を認めるか，大部分に認めて も極めて粗徏のもの） 25 例，円柱上皮を認めるが粗粘 化, 堌殖肥厚等が認められる軽度例は 40 例であつて，

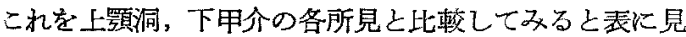
られる如く，上顎洞粘膜病型別では浸潤型に（促つて内

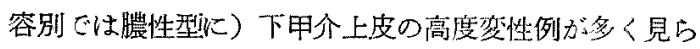
れるが，その他の各項については特定の関係は認められ

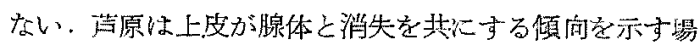
合も胃られるとしているが，私の例ではこれは婈認でき なかつた。 甲介肥大の程度から見礼ば正常例でや上上皮 变性軽度例が多く出ているが，特汇肥厚性骩炎上是られ

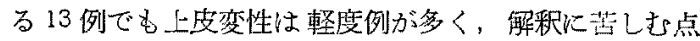
である。

杯状細胞については一般にその出現は少なく，刘照と

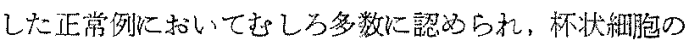

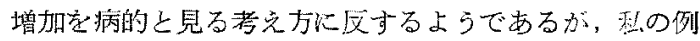
には上皮の脱落例方゙多く含东礼た結果であららか，上皮

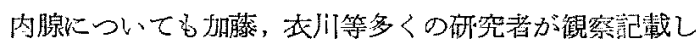

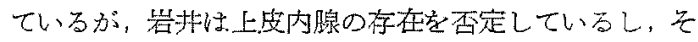

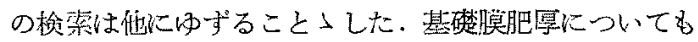

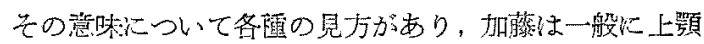
洞蓄㤟症を有するるもの下甲介肥厚が著明で㐫たとし ているが，私の例では高度肥厚は3例にすぎず，殆ん

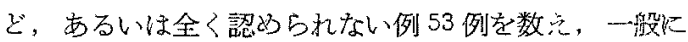

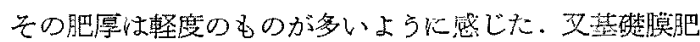
屌と上碩洞粘膜病型，発育度等各項について分類してみ ても一定の閂係は認めることができなかった。

第 15 表 下甲介上皮要性の上鄂润粘膜病型，内容

\begin{tabular}{|c|c|c|c|c|c|c|c|}
\hline \multirow{2}{*}{\multicolumn{2}{|c|}{ 上顠 洞 }} & 粘 & 膜 & 望 & 㗲 & 溜 & 液 \\
\hline & & 線 & 浮 & 浸 & 膦 & 粘 & 㩽 （盆） \\
\hline \multirow{3}{*}{ 上皮変性 } & \pm & $13(39.7 \%)$ & $17(44.8 \%)$ & $5(18.5 \%)$ & $9(23.7 \%)$ & $9(34.6 \%)$ & $17(48.6 \%)$ \\
\hline & $H$ & $9(27.1 \%)$ & $9(23.7 \%)$ & $12(31.5 \%)$ & $9(23.7 \% 0)$ & $7(26.9 \%)$ & $8(22.9 \%)$ \\
\hline & $H$ & $11(33.2 \%)$ & $12(31.5 \%)$ & $16(59.3 \%)$ & $20(52.6 \%)$ & $10(38.5 \%)$ & $10(28.6 \%)$ \\
\hline
\end{tabular}

第 16 表 下甲介肥大上上皮变性

\begin{tabular}{c|c|c|c}
\hline 変性 & + & $H$ & $H$ \\
\hline 脻太 & + & H \\
\hline$H$ & $20(36.4 \%)$ & $12(21.8 \%)$ & $23(41.3 \%)$ \\
+ & $5(20.8 \%)$ & $8(33.3 \%)$ & $11(45.9 \%)$ \\
- & $10(47.6 \%)$ & $5(23.8 \%)$ & $6(28.6 \%)$ \\
(H) & $(7)$ & $(3)$ & $(3)$
\end{tabular}

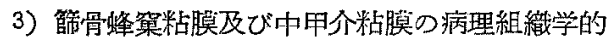
所見之両者の相互関係

節骨蜂窂及び 中甲介の検索例は 43 例（他に正掌と見 られる死体例 2,例) で，その中33 例は同側の下甲介と 共に険索された例であつたが，上顎洞，下甲介に打いて
行つた方法と同様に観祭した結果，表に見られる如く， 全体的に軽症例が多く，従つて病变孔軽度の例が多いが

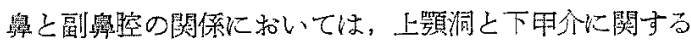
成瀆とほとえど同じであった，又同側下甲介，中甲介間 の2,3の所見についての比整は表の通りで，粘㮠病型

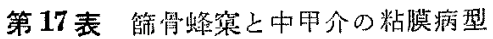

\begin{tabular}{|c|c|c|c|c|}
\hline & & & 篩骨蜂璂 & 中 甲 介 \\
\hline 㼛 & 維 & 型 & $11(25.6)$ & $13(30.2)$ \\
\hline 桴 & 挝 & 型 & $17(39.5)$ & $18(41.8)$ \\
\hline 漫 & 潤 & 侽 & $7(16.3)$ & $12(27.8)$ \\
\hline 释 & 征 & 例 & $8(18.6)$ & \\
\hline
\end{tabular}


においてい中甲介，笠骨蜂窗共に浮腫型が最も多く，中

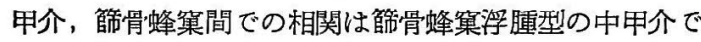

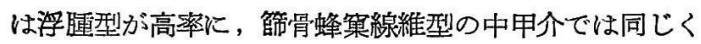
線維型が最も多く認められた．即ち下甲介と上顎洞との 間に認められたと同様に粘膜病型においては篩骨洞と中 甲介の間にも一定の相関が認められた。

海線体血管壁の肥厚について，下甲介と中甲介とを同 一側に得られた 33 例について比較してみると, こっに は明らかな相関は認められず，同様に腺の增減でも一定 の関係は認め難い結果が得られた。

第 18 表 節骨蜂巢粘膜病型と中甲介 粘膜病型 (\%)

\begin{tabular}{|c|c|c|c|c|c|}
\hline 箁点 & & & 緑 維 型 & 浮 腫 型 & 浸 潤 型 \\
\hline 緑 & 維 & 型 & $5(45.5)$ & $4(36.4)$ & $2(18.2)$ \\
\hline 浮 & 腫 & 型 & $4(23.5)$ & $9(56.0)$ & $4(26.5)$ \\
\hline 浸 & 澗 & 型 & $2(28.5)$ & $4(57.2)$ & $1(14.3)$ \\
\hline 軽 & 症 & 例 & $2(25.0)$ & $1(12.5)$ & $5(62.5)$ \\
\hline
\end{tabular}

第 19 表 海線体血管壁肥厚（\%)

\begin{tabular}{cl|r|r|r|r}
\hline 中甲介 & 高 度 & 中 等 & 軽 度 & \\
\hline \hline 高 & 度 & $1(33.3)$ & $1(33.3)$ & $1(33.3)$ & 3 \\
中 & 等 & $1(7.3)$ & $2(14.3)$ & $11(78.5)$ & 14 \\
軽 & 度 & $4(25.0)$ & $3(18.9)$ & $9(56.5)$ & 16 \\
& & $6(15.2)$ & $6(18.2)$ & $21(63.6)$ & 33
\end{tabular}

第 20 表 腺 の 增 減 (\%)

\begin{tabular}{|c|c|c|c|c|c|}
\hline \multicolumn{2}{|c|}{$\begin{array}{l}\text { 下甲介 } \\
\text { 中甲介 }\end{array}$} & 增 吅 & 中 等 & 減 少 & \\
\hline 増 & חוחנ & $1(25.0)$ & $2(50.0)$ & $1(25.0)$ & 4 \\
\hline 中 & 等 & $4(23.5)$ & $5(29.5)$ & $8(47.0)$ & 17 \\
\hline \multirow[t]{2}{*}{ 減 } & 少 & $6(50.0)$ & $2(16.7)$ & $4(33.3)$ & 12. \\
\hline & & & $9(27.3)$ & $13(39.4)$ & 33 \\
\hline
\end{tabular}

鼻幅について

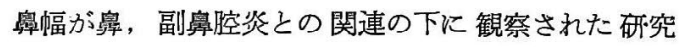

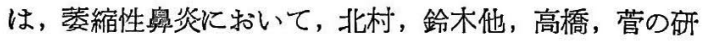
究が見られ，萎縮性鼻炎に特いては，鼻幅は一般に対炤 群より大で，上顎洞は発育抑制型が多い事が認められて いるが，その解釈の点では必ずしも一致していない，一 般の鼻, 副鼻腔炎に際して, 鼻幅を考慮に入れた研究は
比較的に少ないのであるが，高橋（研）の番内整形手術 の考え方に悬腔の形態の重要性が認められており, 最近 では高橋（良）一派の鼻固有聅患についての一連の研究 が見られるが，その組織学的研究は見られないよらであ る. 部坂, 浜野は高橋の分類による鼻内所見之副鼻腔発 育度との関倸を観察しているが鼻幅について特に記載が 見られない、私は, 私の鼻, 副鼻腔炎の組織学的観察に おいて得られた各項の成績について鼻幅の点からも検討 を加えたので，その成續を一括して表に示す（第 21,22 表) (第 4 四).

第.21表 番门と上顎洞発育度 (\%)

\begin{tabular}{|c|c|c|c|}
\hline 巾j & 良 & 中 & 抑 \\
\hline 大 & $9(28.1)$ & $1(33.3)$ & $9(28.1)$ \\
\hline 中 & $17(53.1)$ & $16(44.5)$ & $13(40.7)$ \\
\hline 小 & $6(18.8)$ & $8(22.2)$ & $10(31.2)$ \\
\hline
\end{tabular}

第4図鼻 ヴの計测

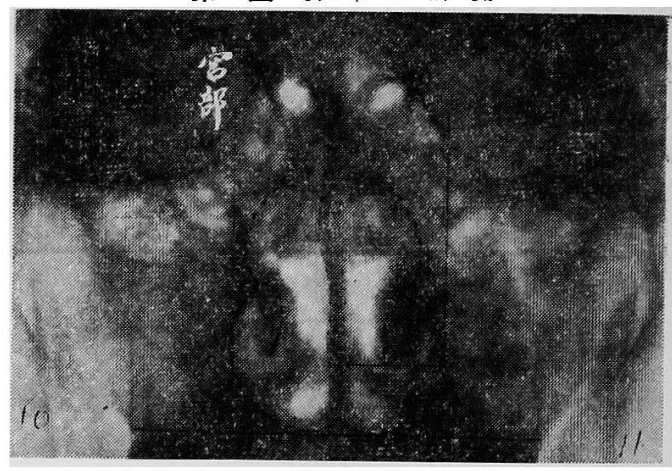

鼻幅は解剖学的には骨鼻腔に括ける梨状口の最大横径 であるが，私はレ線写真上においてこれを計測し，且つ 鼻中隔によつて略 2 分される扁測の横径を以つて仮に鼻 幅と乎んでいる. その值は最小 $13 \mathrm{~mm}$ より最大 $23 \mathrm{~mm}$ で, 16〜 $18 \mathrm{~mm}$ のものを中等とし, $19 \mathrm{~mm}$ 以上を大, $15 \mathrm{~mm}$ 以下を小として, 小 24 例, 中 46 例, 大 30 例を 得た.なお $17 \mathrm{~mm}$ の值の例が 17 例で最高であつた. 鈴木他の菱縮性鼻炎と鼻副鼻腔の大きさとの関係に示さ れる対照群の 鼻幅は $3.60 \mathrm{~cm}$ の平均值を示しており， 高橋他の 同対照群に和!子る鼻幅の平均値は, 男子 3.88 $\mathrm{cm}$, 女子は $3.70 \mathrm{~cm}$ であつて, 私の例でも舅中隔の厚. スを考慮すればほぶ同様な値である.

鼻幅と上靧洞発育度との間には特別の関係は認め.られ ないが，鼻幅と下甲介の組織所見との関係においては， 


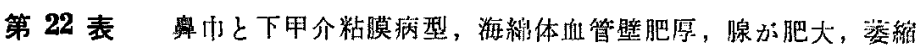

\begin{tabular}{|c|c|c|c|c|c|c|c|c|c|}
\hline$T \pi$ & 战 & 膜 & 型 & 血 & 譬 & 厚 & 腺 & 肥大， & 淁 \\
\hline & 浮腫型 & 緑維㤠 & 浸澗型 & - & + & H & 大 & 中 & 筑 \\
\hline 大 & 11 & 8 & 11 & $23(76.7 \%)$ & $4(13.3 \%)$ & $3(10.0 \%)$ & $8(26.7 \%)$ & $15(50.0 \%)$ & $7(23.3 \%)$ \\
\hline 中 & 15 & 12. & 19 & $30(65.2 \%)$ & $5(10.9 \%)$ & $11(23.9 \%)$ & $2(350.0 \%)$ & $8(17.4 \%)$ & $15(32.6 \%)$ \\
\hline 小 & 2 & 14 & 8 & $11(45.8 \%)$ & $6(25.0 \%)$ & $7(29.2 \%)$ & $8(33.3 \%)$ & $6(25.0 \%)$ & $10(41.7 \%)$ \\
\hline & 28 & 34 & 38 & & & & & & \\
\hline
\end{tabular}

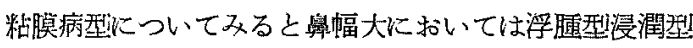
が同率で線維型がやフ少く，舅幅中等のものでは浸潤型 が最も多く見られ次いで浮腫型，線維型の順であって， 又鼻幅小では，線維型が最高で浸潤型，浮朠型の順であ

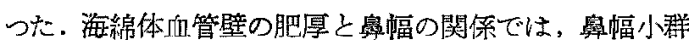
に肥厚例が高率に見られ，腺との関係についてみると， 鼻幅小群に腺菱縮が高率に見られた。

\section{IV. 考按}

慢性副鼠腔炎の病理組織学的研究は，Zucker Kandl がその基礎を策いて以来，Manasse, Hajek, Nuhmannu, Hall, Runge, Eggrton 及び Woltt, Hansel, 西 端及ひ横，出後藤等およびたがしい人心研究によつて 次第に知見を加えてきたが，近年ではとくにアレルギー の主場からの研究が盛んとなり，文粘膜素質と云ら考光 方も Uffenorde, Runge, Mensing 以来各種の角度か ら検傠されている.

Wittmack の中耳蜂巢に和斿る局所体質説が出るに 及えで，この考光方を副學腔に及ぼした研究も多く見ら れるようになり，賛否両論に別れて今日に至つている。

後藤教室に求いては，山野辺，柳野，重野，川原等一

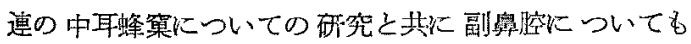
Pn. lehreの立場からの砇究が行われて阿部, 柴时, 節 田等の報告が見られるのであるが，悡虫副鼻腔に和ける

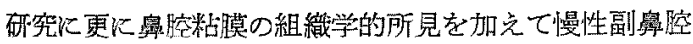
炎及び慢性鼻炎の病理組織学的検討を軾みた。

後藤教室におけるPn. に関する一連の砳究において 示された如く，副鼻腔も又含気腔としてその局所的体質 が認好られたが，その観点から市田は副番腔焱の炎症瑟

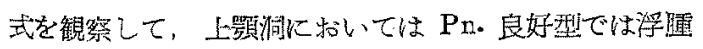
を主徽とするカタル性变化を，Pn。抑制型に批いては線 維性变化を主体之する病型の傾向を，Pn.中等度型に和 いては浸潤の最も強いカルル性あるいは線維性変化の鍇 綜側が热好られることを示したが，私の例でもほぶ同様 の成績が得られた：乙かして，同一個体においては上䝷
洞と下甲介及び箳骨蜂䆵と中甲介が，その终症に対する 発病型式更には粘膜渠質に関与する局所的体質と云ら点 に批いて同質の傾向を持つだろらことは，その発生学上. の位置からみても予想せられることであるが，悡の副番 腔粘膜之甲介粘膜についての対比観察に拀いても，炎症 の主徽である浮腫と結合織增殖の点に祘いて明らかな相: 関が認められた。

しかして上顎洞に和ける粘脱菜質を支配する重要な因 子の一つとして Pn. 型式の関与を諗》る考え方促え ば，下甲介も又上颚洞 Pn。の関連の下にその粘膜菜質 か汧成せられていることが想せられ，この場合上勔洞 Pn.に上つて示される局所的体買は上顕骨乞のもの>局. 所的体質と見做しうることになる。このことは萎縮性鼻 炎に掠いて上影骨の発青抑制が一般に認められているこ

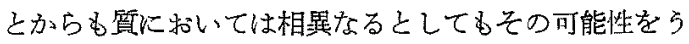
から゙うことができる。しかしながら一方には无上顎洞と 下甲介では同方向の粘膜糸質を示しつつも全体的にはそ の程度に差異加認められる。上顎洞はより浮脾的に，下 甲介はより線䊒化の方向変化する傾向が認められる。 下甲介を台気腔と見ることはできないが，それ故に，上， 顎骨の持つ局所的体質に基く同じ粘膜菜質が含気腔を形. 成する上颚洞に扮いて上り浮䐺性の反応を示すのであつ て，節骨蜂寨と中甲介にも同樣のことが認められる。こ の事は上顎洞上りもより高次の含気化状態にある篩骨䗋 察及び中甲介が，上顎洞及び下甲介上りも夫々一曾浮腫 性変化の傾向を强く示盯事实も推察されよう。

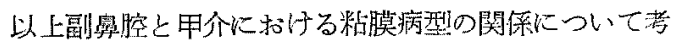
察したのであるが，その优の所見即ち上皮の变性，基礎

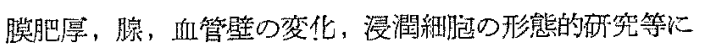

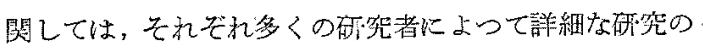
結果が報告されて䄸り，留はこの点での詳細な記載をな 寸程の充分な成縝を持つていない，唯これらの各所見の 中で腫脤体と呼ばれる血管群比ついては稍々詳細な観察 を斌欢たと思うので主としてこの点既ついて考察を進め。 
代い，番甲介粘膜についての組織学的研究も又，多数に 見られるのであるが，上皮，腺，浸潤細胞等に関しては 夫々詳細な観察がなされているのに比べると，血管とく 饮海線体血管に関しては詳細な研究が此較的炕少ないよ 5に思各れる，血管の変化は，古来慢性炎定の主要な変 化として重要視され，近年とくにアレルギー研究の発展 上共炕をすすすとの重要性を加えつ」あるが，海綿体血 管はその構造の上からも又機能の点からも一般の血管と は稍そ趣を異にするものである，この意味から私は特に 㮔脹体とも云わ扎る海綿体について稍々詳細な観察を試 みたのであった。

即ち海綿体血管壁の肥厚の程度，管腔拉脹の強弱と上 頻洞及び下甲介の粘膜病型之の関係，あるいは下甲介肥 大との関係について検訫した結果は特に著しい相関は認 められなからたのであって，この管壁の肥厚は必ずしも 他の炎症所見之並行世ず，正常に近い例机いても多数 例に管壁の肥厚が認められるのであつて，この重実から みれば，海綿体血管壁の肥厚は，局所体質に基くある種 の粘膜索貿が存在して，それに左右されることが大きい もの之推察される。文従来研究者の多くが一般に血管壁 の内膜あるいは中膜の肥厚像として観察記載してきたい わゆる胼隆起については，私は遭続切片並びにその拡大 写真化基く管腔の複溝換型について観察を訊みた。一般 飞血管壁の炎症性変化として内獏，中膜の肥厚が起るこ

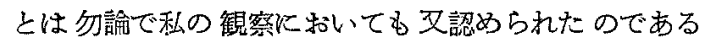
が，海綿体血管の場合においてこのような変性に基く形 の上での変化は軽度のものであつて, いかゆる胼隆起と されているものはこれら変性とは直接無関倸に, 睡脹体 の構造上当然存在するるのである. 即ら海綿体の構造を 最も単純化し，その最小の草位にした型を芩えるならば いわゆる铭鈴型と見る事ができる。これを模型的に観察 すれば次の如くなる，即ちその盺面像は $\left(1^{\prime}\right) ，\left(2^{\prime}\right) ，\left(3^{\prime}\right)$ の各相が現れ，第 2 相が即ち筋隆起として見られる所で あつて，この部分には一般に結合織が豊富であり従つて 又弾力線維が多く見られることは芦原も記載している通 りである. 又この筋隆起と腫脤体の機能との関係を考察 するに，この舆鉿が膨脹す机ば当然に（4）の型となる。 海綿体血管壁隆起の認められない相は，(4) あるいは （2）火相当するものである.この(4)の型の存在は弾力 鳈維によって観察されるのであつて，私の例に括いて (2)，(3)，(4) の各相炕相当与万弾力線維像が多数热凶 られ，隆起を認めない管壁に和いてもその全周に㚬等に ではなく、ぼ゙相対する 2 ケ所において弾力線維の集合
像が見られることが多い，従つて缰脹体としての機能に 最も関与する部分はこの施隆起あるいは弾力線維の多、 ・部分であつて,この部分の收縮, 伸展が海綿体機能の主 体であると見ることができる、私は臨床的水っカン， アドレィリンに対する下申介の反応と，々の海綿体血管 壁の像之の関係化よつて, 組織像と機能との関係を求 め, 又管壁の肥厚，笳突起と他の組織所見との関係につ いても観察を語みたが一定の関係は認められず，この点 の解明は他日にゆずることつした。
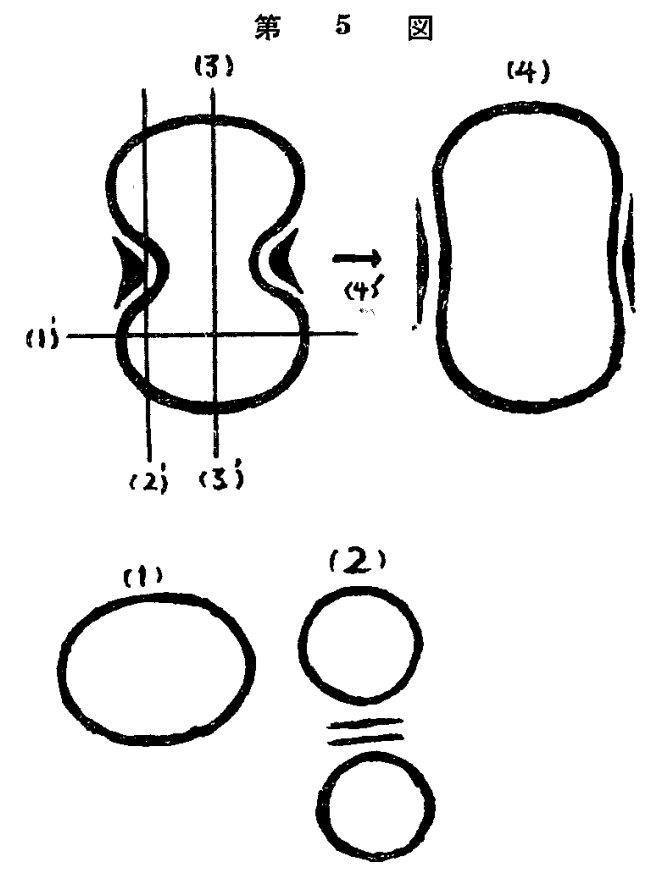

鼻幅については主として秵副鼻腔の臨床所昌との関保 において, 特に菱縮性奥炎に対しては詳細な研究が見ら れるが，一般の鼻副嶨腔炎とくにその組織学的所見之鼻 幅との関係についての研究は見られないので，私の組織 学的研究に際して鼻楅を計測して2,3 の検討を誠みた のであるが特別の知見は得られなからた。

\section{$\mathbf{v}$, 結語}

1）慢泾副鼻腔炎についてその粘膜病型を観察し，併 せて鼻甲介の粘膜にていても病理組䄉像を観察して両者 の相互関保について㭘討を試みた。

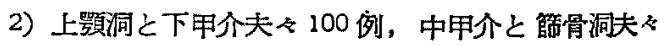
43 例についての成績では, 上顎洞浮婳型の下甲介は浮

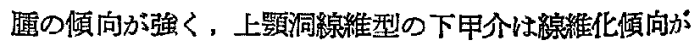
強い：この関保は節骨蜂煲と中甲介についてい同様であ 
つた

3）笘骨蜂案は上影洞よりも，中甲介は下甲介よりも 夫々，浮連が高率に認められた。

4）上皮変性，基礎膜肥厚，浸潤細胞，腺及び血管壁 の変性については，甲介之副鼻腔の間で一定の相関は認 めら礼なからた。

5）甲介の海綿体血管壁についてその連続切片及び 復 構模型によつて観察を試みた結果，いるねる筋隆起とさ れているものは值接, 血管の内膜, 中膜の肥厚と関俰が なく，すべて病的と見ることは当らない，㕛管壁の厚さ む他の炎症所見之並行せず，且つ䠦床所見から比較して も，资症高度のものに肥厚が多く，高度に現れるとの成 結は得られず，却つて甲介の腫掁肥厚の軽い例にこの䋉 隆起が渚明であつて，その発達の程度はもしろ局所体質 に基く粘裳萃質によつて左右されているものと見做され た.

6）鼻副穿腔の臨床所見及び組織学的所見と 鼻幅の関 係沉いても観察した結果，萎縮性學炎に打ける上顎洞 発巟度之鼻幅の間任見られる如き，明らかな相関は認め られなからた。

\section{主 要 文 献}

1) Manasse, P.: Zschr, f. HN. u OH. k. 4: 473, 1923. 2) Eggston, A. and Wolff, D.: Histopat. hology of the Ear, Nose, and Throat. 1947. 3) Citelli, S.: Arch. f. Laryng. u. Rhino. 13: 89, 1903. 4) Hajek, M.: Arch, f. Laryng. u Rhino. 17: 95, 1905. 5) Brunner, H.: Nasal glands. Arch. of otol. 35: 183, 1951. 6) Vogel, G.: Denker und Kahler's Handbuch der Hals Nasen, und Oh. renheilkunḋe. Bd 2:1928, 7) Zarniko: Die Krankheiten. der Nase und der Nasenrachens Aufl. 3:1900. 8) Zuckerkandl: normal und pathologische Anatomie der Nasenhöhle 1892. 9) Hansel: Allergy of the Nose and paranosal sinuses 1936. 10）声原：舅甲介の病理解剖学的研究追䊒，第一，下 奥甲介の老性变化に就て, 愛知医学, 34 ; 上 182, 1927. 11）苫原：下甲介肥大症の組織所見について，愛知医 学，35；4，1928.12）芦原：胎児及び初生児下甲分 の組織学的所見に就て，愛知医学，34；2，13）加

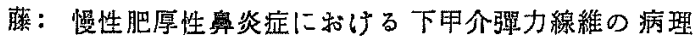

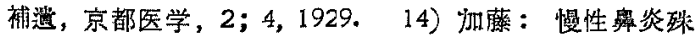

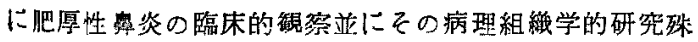

に上皮の態度に゙就て，京都府医，3；5，1930。

15)衣

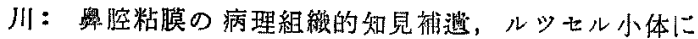
ついて，日耳與，34；779，1931，16）日下：下甲尔 に関する臨床的研究，耳鼻臨，49；218, 17) 松本：

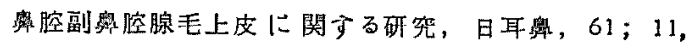
1956. 18) 原：鼻腔粘膜の実䑐病理学的砄究, 日耳

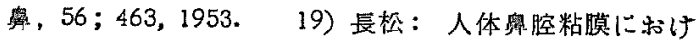

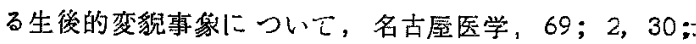
$1920)$ 坂井: 慢性副舜腔燚の細胞病理学的研究, 特に゙洞粘膜に゙款ける形貿細胞に゙就て，耳候科，28；5，3， (1956. 21) 望月：奻小坚鼠副舅腔炎の病理組織学的， 研究，耳番臨，49：20，1956.22）高橋：率腔所見上 り総掊的に見た所謂奥固有疾患の区別に゙ついて，日耳 奥，53；9，1950. 23）部坂・浜野：奥内所見と副奥 腔発亩度洞病变との関係，日耳番，59；5，1950。24)

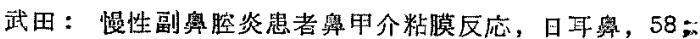

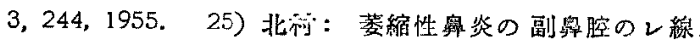

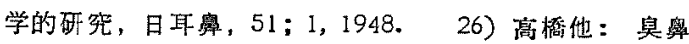

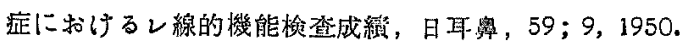

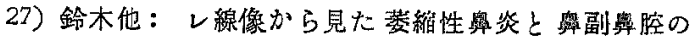
大いきとの関保に゙ついて，日耳奥，61；1，1959. 28)。 管：菱縮性鼻炎と上覆洞発育度との関係に゙ついて，日

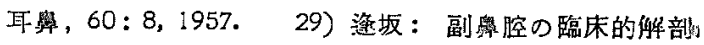
に関する研觉，耳鼻臨，45；33，1952. 30) 持山：人 胎児の副奥腔の形態的発育に就いて，正鼻臨，47：440, 1954. 31) 吉川：上颚洞の発育程度と颜型との相関々 倸に就いて，耳鼻隐，37：687，1942。32) 西端・㯕 出：日本耳孟咽搌科全書，第 2 卷，1955. 33）仁保，

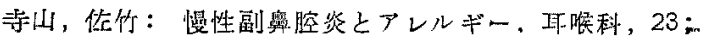

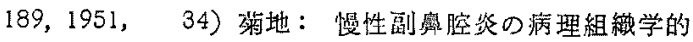
研究，日耳鼻，58；206，1955.35）美：慢性奥炎及

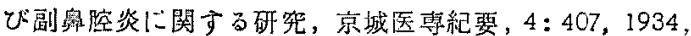
36）山野辺：副舆腔発育機枟とその初期に認妙られる 潜在性炎症様所見 (所買先天潜在性副舅腔炎に就て) ,

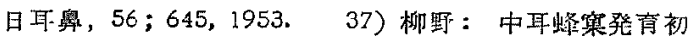
期に見られる炎症様所見に関する研究，日耳幾，56：

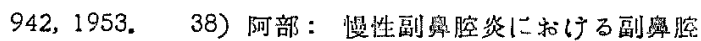
Pn。粘膜及び骨壁の病変との関倸に゙就て，日耳萛，

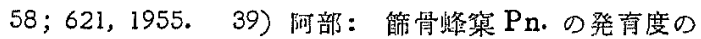
際床的判定に就いて，日耳鼠，58；476，1955.40) 北 川：慢性副奥控炎に肪ける形質細胞の発生に就て，耳 喉科, $22 ; 75,1950.41$ ) 吉野：慢性副㕰腔炎の病理 


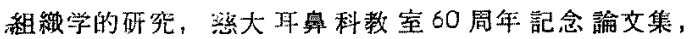
1953.42）河利：上颚润粘膜の細胞像に゙就て，日耳

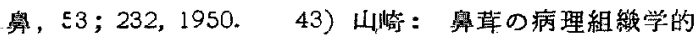
研究，日耳舆，57；922,931，1954.44）山田, 石川: 慢性上罰润炎に゙現われる土ホジン啫好細胞に゙就て，日耳 舜，55；197，1952.45) 天野：形質細胞, 日血会誌, $9 ; 25,1946.46)$ 川原: 乳様峰笨再生に関与石研究

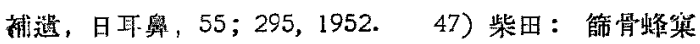
再生の実驗的研究，日耳楀，56：838，1953.48) 重

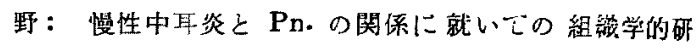
宛，日耳泈，58；469，1955. 49）方:田：慢性副鼻腔

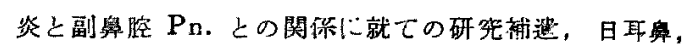
60；377，1957. 50) 後耀：PD.の成立を之の臨床,

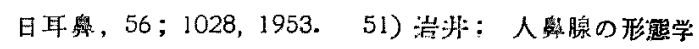

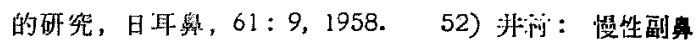

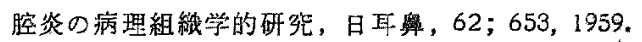

（原㩦到着=胎和 34.11 .30 日一急載） 
小林論文付図（I）

第

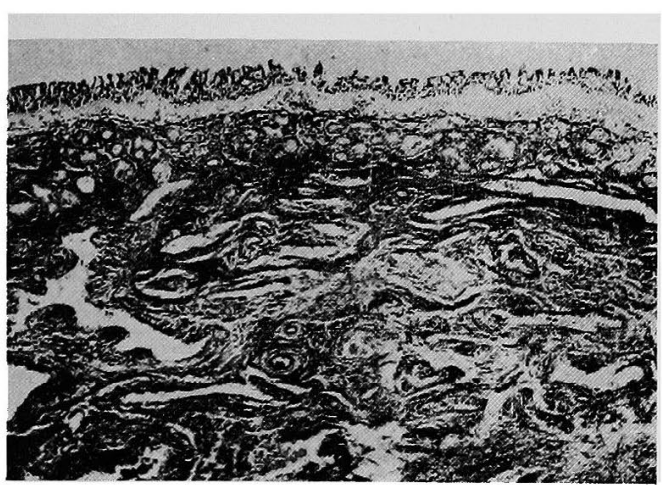

1. 線 維 型

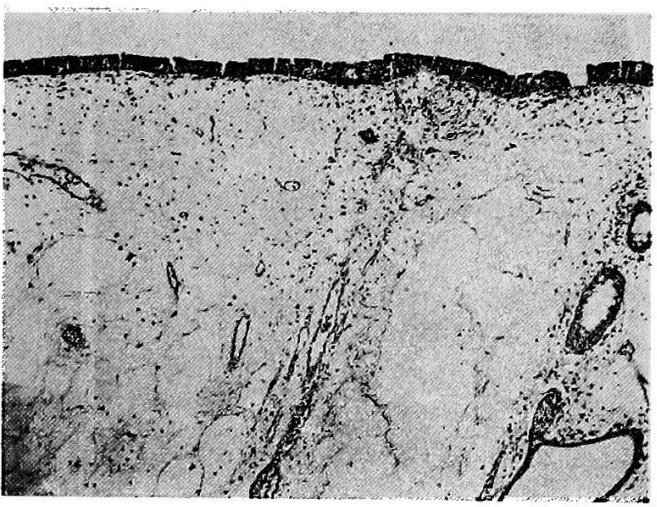

2. 浮 婳 型

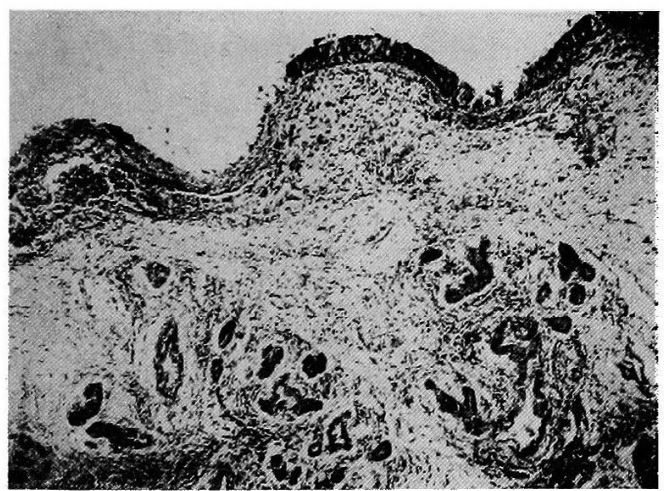

3. 腺 萎 縮

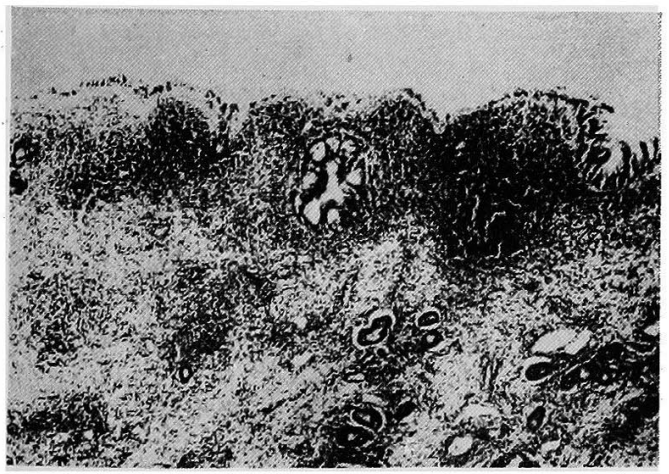

5. 高度浸㵍

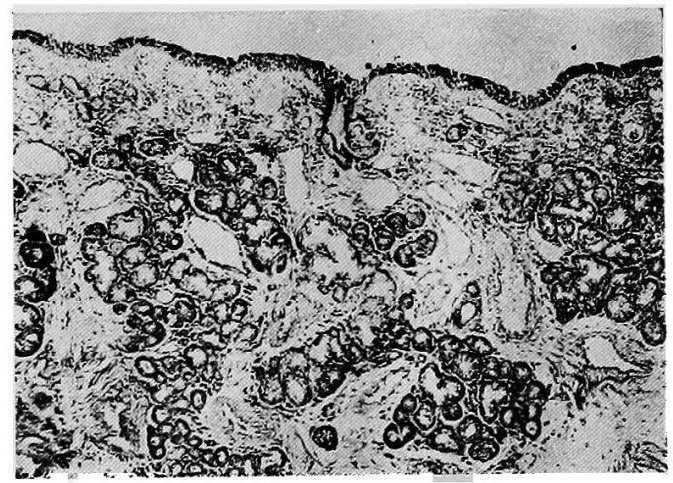

4. 腺 正常

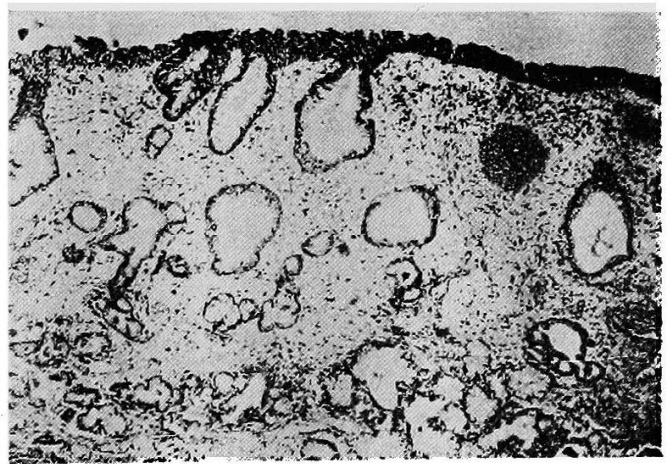

6. 腺拡大 


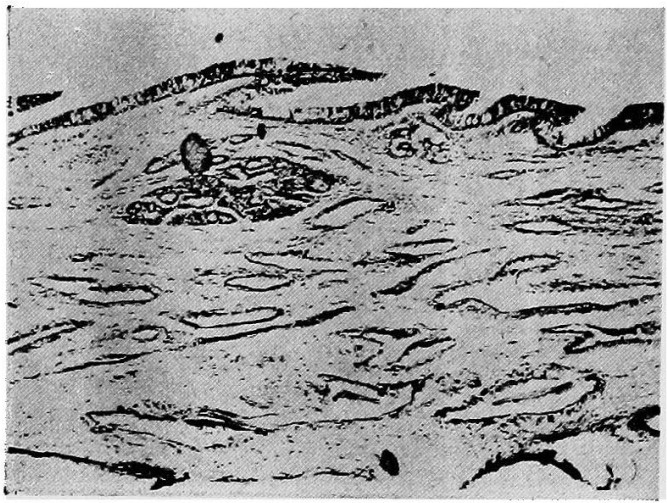

7. 正常中甲介（死体例）

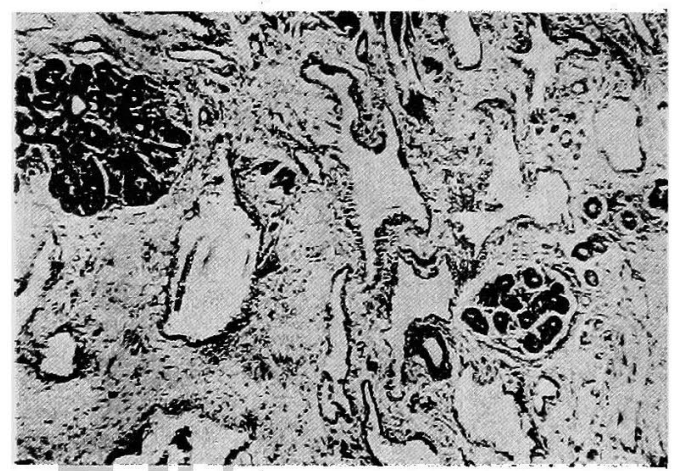

9. 海線体拡脹，管壁蒲い

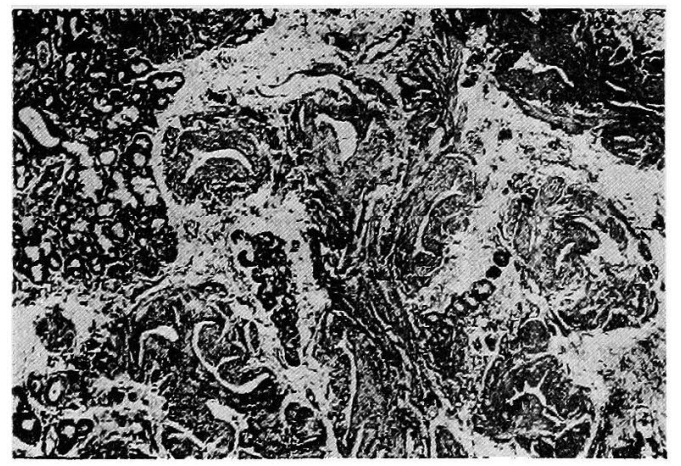

11. 深綿体血管壁の肥厚著明

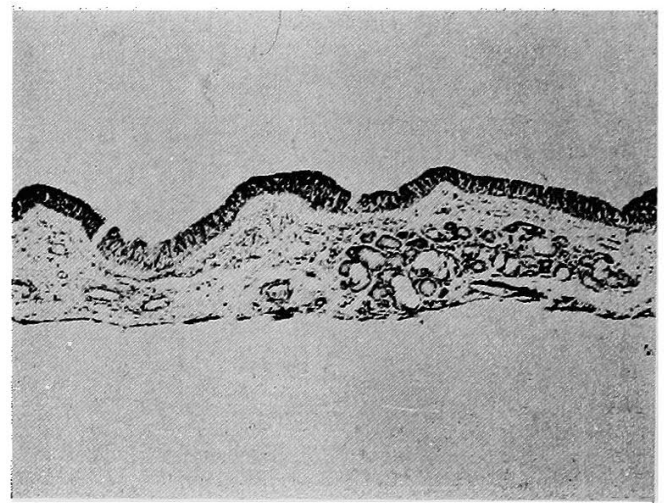

8. 正常節骨蜂窠 (死体例)

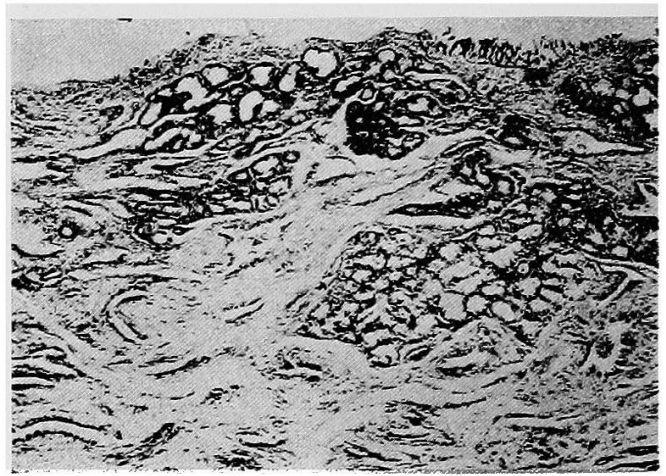

10. 正常死体例 7,8 の下甲介

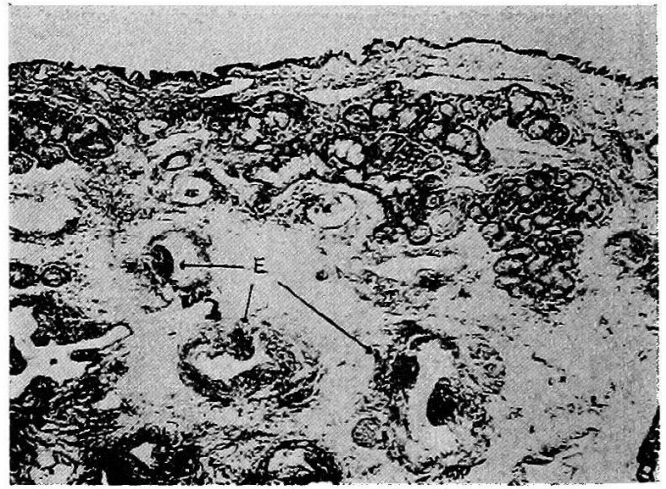

12. 海線体筋隆起と彈力線維 (E) 